\title{
Vertaling en/as abjeksie: Antjie Krog
}

\author{
Franci Vosloo \\ Departement Afrikaans en Nederlands, Universiteit Stellenbosch, Suid-Afrika \\ Epos: francivosloo1@gmail.com
}

\section{Opsomming}

Internasionaal bekroonde skrywer en digter Antjie Krog, skryf in Afrikaans, haar moedertaal, vertaal ander se werk (Nederlands en Vlaams) in Afrikaans, en vertaal haar eie werk (saam met ander vertalers) in Engels. As tweetalige en veeltalige skrywer werk Krog voortdurend op 'n dialogiese en heteroglossiese vlak binne 'n komplekse sosiokulturele en sosiolinguistiese omgewing. Met die skep van tekste wat twee- of veelstemmig is, stel Krog veranderende betekenisse en ontvanklikheid vir verskillende perspektiewe aan die leser bekend - 'n proses wat dikwels haarself, haar taal en ander se taal ontheem of vervreem. Hierdie artikel ondersoek die abjekte soos dit in Krog se teenwoordigheid as selfvertaler en vertaalde skrywer in die SuidAfrikaanse literêre veld manifesteer. Die abjekte - dit wat onvanpas en vuil is en die geordende sisteem bedreig - is die duidelikste teenwoordig in ons (as subjektiewe persone) reaksies op die fisiese liggaam en die moontlikhede van kontaminasie wat dit inhou. Die skryfproses en die inhoud daarvan, kan en behoort op soortgelyke wyse as ontwrigtende handelinge te funksioneer. Die konsep van die materialiteit van die teks is spesifiek relevant tot Krog se eie poësie, wat 'n abjekte, beliggaamde landskap voorstel. As skrywer bewoon (inhabit) Krog die teks - sy wórd die ritmes en artikulasies van die teks. Binne kulturele vertaling, vorm abjeksie en die mineuraanwending van taal 'n integrale deel van die konstruksie van identiteit en subjektiwiteit. Hierdie abjeksie funksioneer op twee vlakke: aan die een kant is Krog se teenwoordigheid binne die Engelse literêre veld ambivalent, onstabiel en uitdagend van 'n skoon, geordende sisteem; aan die ander kant ondermyn sy die majeurtaal deur haarself met subversiwiteit te vertaal. Die doel van die artikel is om die konsepte abjeksie en mineurtaal te versoen in 'n poging om 'n vars perspektief te gee op die persepsie en resepsie van Krog se werk in die Suid-Afrikaanse literêre veld.

Sleutelwoorde: abjeksie, literêre vertaling, vertaling en hibriditeit, Antjie Krog, mineurletterkunde, Kristeva, Deleuze en Guattari

\section{Translation and/as abjection: Antjie Krog}

\section{Extended abstract}

Internationally acclaimed South African author and poet Antjie Krog writes in Afrikaans, her mother tongue, translates others' work (Dutch and Flemish) into Afrikaans, and together with other translators, translates her own work into English. As bilingual or multilingual writer in a complex sociocultural and sociolinguistic environment, Krog continually operates at a dialogic 
and heteroglossic level. In producing texts that are double-voiced or multi-voiced, she introduces differing meanings and openness to different perspectives, often defamiliarising herself, her own and others' language, and the reader.

This paper seeks to address the notion of the abject as manifest in Krog's presence as selftranslator as well as in her presence as translated writer in the South African literary field. The abject - that which is improper, unclean, threatening the orderly system - is most prevalent in our (subjective beings') reactions to the physical form of the body and its contaminative possibilities. In a similar vein, writing and its contents, could, and does, function as destabilising acts. The notion of the materiality of the text is particularly relevant to Krog's own poetry, as her work exhibits an abject, embodied landscape. As writer, Krog inhabits the text and becomes the rhythms and articulations of the text.

"God, Death, Love, Loneliness, Man / are important Themes in Literature / menstruation, childbirth, menopause, puberty / marriage are not," Krog writes in Body bereft (BB 20), highlighting, to a large extent, what Mansfield calls "fantasies of an autonomous selfhood" (Kristeva in Mansfield 2000:82): “... we draw an imaginary line around the perimeters of our bodies and define our subjectivity as the unique density of matter contained within that line." This dilemma experienced by the subject could have an additional dimension, namely, "In our fantasy of an autonomous literature or autonomous language $[. .$.$] we draw an imaginary line$ around the perimeters of our literature and define our literature/language as the unique density of matter contained within that line." The latter interpretation of Kristeva links to Deleuze and Guattari's work on minor literature, specifically the hidden potential of a minor use of a major language. Krog's poem also echoes Christiane Rochefort's description of the struggle in terms of freedom of the (French) women writer: "You are supposed, too," she writes (Rochefort in Jones 1997:380), "to write about certain things: house, children, love. [...] Maybe you don't want to write about, but to write, period. And of course, you don't want to obey this social order. So, you tend to react against it" (italics in original).

Krog's oeuvre in the Afrikaans and English literary field in South Africa consists of Afrikaans poetry volumes, prose, prose translations from English and Dutch, and translations of her own and others' poetry. Her first non-fiction book is published in 1995 (Relaas van 'n moord; Account of a murder, 1997), followed by her first publication in English in 1998, Country of my skull. Thereafter followed the autobiographical/fictional work $A$ change of tongue (2003; published in 2005 as ' $n$ Ander tongval), her most recent non-fiction book being Begging to be black (2009). With Country of my skull and A change of tongue Krog acquired international status, but mostly made the transition to bilingual or multilingual writer occupying the interesting yet ambivalent space of hybridity, heterotopias and the cosmopolitan. In 1995 she started working as translator of Nelson Mandela's autobiography into Afrikaans, followed by various translations and anthologies; the most recent being her second anthology in English translation, Skinned (2013).

It is argued that in translating her own work from Afrikaans, a minoritised language post-1994, into a language of power, English, Krog abjectifies the major language, thereby creating a delicate space in the target cultural field: a space where the language is double, vague, heterogeneous, metamorphosed, deterritorialised, reterritorialised; a space where her translations open up "revolutionary conditions [...] within the heart of what is called great (or established) literature" (Deleuze \& Guattari 1986:18). Entering the Afrikaans literary field at a 
stage where it was a major (institutionalised) literature in South Africa, Krog's style was less conventional and her subject matter daring. With Country of my skull, A change of tongue and Down to my last skin, Krog moved from minor (Afrikaans) to major language, utilising a type of English (South African, with heavy Afrikaans undertones) that constitutes a minor use of the major language (see Pakendorf 1993). In Krog's approach to retain the Afrikaans undertones she manages to keep alive the contact zone between Afrikaans and English as a space of multiple articulations where language need not function as a defining or limiting border. It is perhaps safe to position Krog in a hybrid space within the English literary field. This in-between space, or third space, presents itself as uncomfortable and revealing, and as symptomatic of the tension between two more defined spaces from the English reader's perspective: the one known, global, intimidating, levelling (English), the other unknown or foreign (Afrikaans), yet local.

In Deleuze and Guattari's framework, innovation or novelty in language usage is what opposes the attraction of a higher, dominant order, creating a new literary continent or space that is neither conformist nor idealistic. On the level of the abject, Krog creates such a space in Country of my skull and $A$ change of tongue, and again in Verweerskrif and Body bereft, paving the way for the conceptualization of an international and cosmopolitan culture based on the inscription and articulation of cultural hybridity. Moreover, she views translation as the transformation of one text from a powerless language into a powerful one; the transformation of a powerful text that was made powerless by a powerless language, becoming empowered in and through the powerful language (Krog 2002b:2).

As forms of textual and cultural translation, abjection and minoritisation form an integral part in the construction of identity and subjectivity. This abjection is operative on two levels: on the one hand Krog's presence in the English literary field is ambivalent, unstable and daring to a clean, orderly system; on the other hand she undermines the major language by translating herself and her non-orderly self with subversion. The aim of this paper is to merge the concepts of minoritisation and abjection in an attempt to bring a fresh perspective on the perception and reception of Krog's work in the South African literary field.

Keywords: abjection, literary translation, translation and hybridity, Antjie Krog, minor literature, Kristeva, Deleuze and Guattari

\section{Inleiding}

God, Die Dood, Liefde, Eensaamheid, Die Mens

God, Death, Love, Loneliness, Man

is Belangrike Temas

are Important Themes in Literature

menstruasie, geboorte, menopouse, puberteit

menstruation, childbirth, menopause, puberty

die huwelik - nie

marriage are not

tog lê die verskrikking juis in

meanwhile terror lies exactly in how

hoe leef jy met die disintegrerende lyf saam 
one lives with the disintegrating body

hoe aanvaar jy dat die liggaam sig

in how one accepts that the body no longer

nie meer kan intensifiseer tot ' $n$ verruklike knal nie

wants to intensify with exhilarating detonations

hoe bemin jy die al-hoe-meer-blussendes

in how one loves the more-and-more-slaked-ones

hoe berus jy in vaginale atrofie en inkontinensie

in how one resigns to vaginal atrophy and incontinence

of dat die lem wat nou deur jou hart klief

or that the blade cleaving through one's heart

waarskynlik 'n hartaanval is

is probably a heart attack

om van die ouerwordende lyf na Die Dood

to jump from the ageing body to Death

te spring, word al hoe meer 'n cop-out ding

has suddenly become a cop-out act (V 20; BB 20) ${ }^{1}$

Die voorafgaande woorde belig in 'n groot mate wat Mansfield in sy bespreking van Kristeva "fantasies of an autonomous selfhood" noem (Kristeva in Mansfield 2000:82): “... we draw an imaginary line around the perimeters of our bodies and define our subjectivity as the unique density of matter contained within that line." Hierdie dilemma wat die subjek ervaar, sou 'n bykomende dimensie kon hê, naamlik, "In our fantasy of an autonomous literature or autonomous language $[\ldots]$ we draw an imaginary line around the perimeters of our literature and define our literature/language as the unique density of matter contained within that line." Die dilemma wat Mansfield beskryf, skakel met Deleuze en Guattari se werk oor mineurletterkunde, en spesifiek ook die verborge potensiaal wat opgesluit is in die mineuraanwending van 'n majeurtaal. Dít, volgens Venuti (1998:136), is wat 'n geskiedenis van oorheersing belig. Krog se gedig eggo Christiane Rochefort se beskrywing van die dilemma van die (Franse) vroueskrywer ten opsigte van vryheid: "You are supposed, too," skryf sy (Rochefort in Jones 1997:380), "to write about certain things: house, children, love. [...] Maybe you don't want to write about, but to write, period. And of course, you don't want to obey this social order. So, you tend to react against it" (kursivering in oorspronklike).

Krog se oeuvre binne die Afrikaanse en Engelse literêre veld in Suid-Afrika bestaan uit oorspronklike Afrikaanse digbundels, prosawerke, prosavertalings uit Engels en Nederlands, en vertalings van haar eie en ander se poësie. In 1995 verskyn Krog se eerste niefiksie werk, Relaas van 'n moord (Account of a murder, 1997), wat in 1998 opgevolg word deur haar eerste publikasie in Engelstalige literatuur, Country of my skull, en in 2003 met die outobiografiese/fiktiewe werk A change of tongue, wat in 2005 as 'n Ander tongval verskyn. Begging to be black (2009) is haar mees onlangse niefiksie werk.

\footnotetext{
${ }^{1}$ Verwysings na Krog se werk word as volg afgekort: 'n Ander tongval AT; A change of tongue CT; Body bereft BB; Country of my skull CS; die sterre sê 'tsau' SS; Down to my last skin DLS; Kleur kom nooit alleen nie K; Lady Anne LA; Met woorde soos met kerse MW; Otters in bronslaai OB; the stars say 'tsau' ST; Verweerskrif V.
} 
Met Country of my skull en A change of tongue verwerf Krog internasionale status, maar maak sy amptelik die oorgang na twee-/meertalige skrywer wat die interessante en ambivalente ruimte van hibriditeit ${ }^{2}$, heterotopias ${ }^{3}$ en die kosmopolitiese ${ }^{4}$ betree. In 1995 begin Krog ook as vertaler werk met die vertaling van Nelson Mandela se outobiografie in Afrikaans as Lang pad na vryheid, en daarna in 2000 Henk van Woerden se biografiese roman uit Nederlands in Afrikaans as Domein van glas. In 2002 vertaal sy Tom Lanoye se drama Mamma Medea in Afrikaans as Mamma Medea: na Apollonios van Rhodos en Euripides. Heel resent verskyn Krog en André P. Brink se vertaling van Ingrid Jonker se gedigte, Black butterflies (2007) asook haar tweede versamelbundel in Engels, Skinned (2013).

In hierdie artikel val die fokus op sowel Krog se eie vertalings van haar eie poësie uit Afrikaans in Engels as op gedigte wat deur ander vertaal is, met spesifieke verwysing na die bundels Down to my last skin en Verweerskrif/Body bereft. Ek beweer dat Krog, in die proses van die vertaling van haar eie werk uit 'n mineurtaal/-letterkunde in 'n taal van mag, die majeurtaal abjektifiseer. Hierdeur skep sy 'n delikate tussenruimte of grens in die doeltaal: 'n grens waar die taal dubbel, vaag, heterogeen, gemetamorfeer is. Hierdie abjeksie vind op twee vlakke neerslag: aan die een kant is Krog se teenwoordigheid (soos ook in die geval van ander se vertalings van haar werk) in die Engelse literêre veld ambivalent, onstabiel, en daag dit die 'skoon, ordelike' sisteem uit; aan die ander kant ondermyn sy die majeurtaal deur haar nieordelike self en haar nieordelike taal met subversiwiteit te vertaal.

\section{2. 'n Suid-Afrikaanse literêre veld: kort oorsig}

Oor die diskoers van 'n nuwe verenigde Suid-Afrikaanse literêre sisteem wat veral ná 1994 posgevat het, was daar sterk uiteenlopende menings. Die sterkste pogings tot die bespreking van 'n Suid-Afrikaanse literatuur het vanuit die geledere van die literatuurgeskiedenis gekom. Hoewel die diskoers "rondom die bestaan (of wenslikheid) van 'n Suid-Afrikaanse en/of nasionale letterkunde" volgens Roos (2006:99) in resente tye alreeds afgeplat het, en nie regtig meer aandag geniet nie, kontekstualiseer dit nogtans die posisie wat Afrikaanse skrywers deesdae binne die Engelse literêre veld in Suid-Afrika beklee en vice versa. Volgens De Kock (2001:267) het die oneweredige ontwikkeling van Afrikaanse, Engelse en inheemse literatuur, oftewel kulturele verbastering, veroorsaak dat daar selde na 'n geïntegreerde Suid-Afrikaanse literêre veld verwys word. Volgens Van Wyk Smith (1996:75) is daar byvoorbeeld geen onbetwiste bewys dat skrywers binne 'n bewussyn van "een letterkunde" skryf nie. Die skeiding tussen die Engelse en Afrikaanse literêre tradisie, en die problematiek by pogings om die twee te verenig, het volgens John (2005) te doen met die "dominant orientation of the English South African literary critical tradition, namely its privileging of politics over aesthetics." De Kock (2001) voel voorts "Suid-Afrikaanse literatuur" as 'n veld is niks meer as die empiriese basis daarvan nie, en allermins 'n selfstandige, outonome veld. Van die mees onlangse pogings vanuit die literatuurgeskiedenis om die literêre veld te verenig is dié van Chapman, Southern African literatures (1996), Heywood, A history of South African literature (2004) en Ndebele,

\footnotetext{
${ }^{2}$ Hibriditeit as konsep belig veral die 'feit' dat identiteit - rasse- en etniese - meer simbolies as werklik is, en beslis meer arbitrêr as natuurlik (Mansfield 2000:133).

3 "Characteristic spaces of the contemporary world, heterogeneous spaces of sites and relations, the spaces in which we live, which draw us out of ourselves" (Vidal Claramonte 2012:271).

${ }^{4}$ Die kosmopolitiese skrywer of subjek weerspieël "ways of living at home abroad or abroad at home - ways of inhabiting multiple places at once, of being different beings simultaneously, of seeing the larger picture stereoscopically with the smaller" (Breckenridge et al. 2000:587).
} 
Rediscovery of the ordinary: essays on South African literature and culture (2006). Volgens De Kock (2001:271) is die geheelbegrippe 'n Suid-Afrikaanse literatuur of letterkunde problematies: daar is bloot te veel onsekerheid en vrae oor kwessies soos die kolonisasie van kultuur, kanonisering en die ontwikkeling van tradisie, literêr-kritiese historiografie, identiteit, die materialiteit van diskoersregimes, die konstruksie van kultuur, en die verhouding tussen mag en kulturele produksie.

Volgens Roos (2006:90) is die afwesigheid van 'n nasionale identiteit die gevolg van SuidAfrikaners se geskiedenis van verdeeldheid. Die literêre diskoers oor identiteit is gevolglik veelstemmig en hibridies van aard, en 'n aanduiding van die teenwoordigheid van 'n interkulturele proses binne die Suid-Afrikaanse letterkunde(s). 'n Interessante verskynsel is dat Afrikaanse skrywers en digters al hoe meer hulle werk feitlik gelyktydig in Afrikaans en Engels (Brink, Marita van der Vyver, Breyten Breytenbach), in dieselfde bundel in Afrikaans en Engels (bv. Elisabeth Eybers, en Breytenbach) of selfs toenemend in Engels (Breytenbach) publiseer. Ook word die bestaande Afrikaanse literêre sisteem aangevul of uitgebrei deur die invoer van nuwe modelle, boeke, temas uit inheemse literatuursisteme maar ook uit uitheemse sisteme soos die Lae Lande (Van Coller 2005:41). Krog publiseer soms slegs in Engels (Country of my skull 1998), aanvanklik in Engels en daarna in vertaling (A change of tongue / 'n Ander tongval 2003, 2005a), asook gelyktydig in Afrikaans en Engels (Verweerskrif /Body bereft 2006a, 2006b). Volgens Roos (1998:32) word "gevestigde aannames en ideologieë ondermyn" deur die verskeidenheid nuwe tekste binne die Afrikaanse kader; temas en karakters wat tradisioneel op die rand van die sentrum van die sisteem gestaan het, is (of het) nou na die sentrum verskuif. Nederlandse werke wat byvoorbeeld met die dominante ideologie in Suid-Afrika versoenbaar is, word gunstig oorweeg vir opname in die Suid-Afrikaanse sisteem (deur vertaling deur prominente vertalers). Opname in die sisteem beteken egter nie dat dié werke, soos die meeste vertalings in Suid-Afrika, skielik in die sentrum van die sisteem staan nie. Die vraag is steeds of hierdie werke deur gebruikers gekoop en gelees word.

Die enkele vermeldings in die Afrikaanse literatuurgeskiedenisse van vertaling en skrywers wat as vertalers werksaam is (en was) staan in sterk kontras met die aandag wat oorspronklike literatuur in hierdie kanoniseringswerke kry. Tog is dit simptomaties van die werklike posisie wat vertaalde literatuur en vertaling as handeling binne die algemene Afrikaanse literêre veld in die 20 ste en begin van die 21 ste eeu beklee, naamlik 'n randposisie. Die rede vir die randposisie in veral die vorige eeu is waarskynlik meer voor die hand liggend as wat aanvanklik vermoed is. Daar kan sover gegaan word deur te sê dat die afgelope eeu daar in al die ontwikkelingstadia van die literatuur 'n sterk politieke, polities-aktuele en sosiopolitieke bewussyn teenwoordig was. Die verwagting is dat die gereelde en grootskaalse veranderings op sosiopolitieke gebied noodwendig ruimte sou skep binne 'n literatuursisteem vir vernuwende invloede van buite of selfs vanuit die randgebied van die sisteem. Die nasionalistiese gedrewenheid van vroeër, die preokkupasie met verset en betrokke literatuur, die sosiale kommentaar, die voortdurende politieke blik van die skrywer, ensomeer, blyk die literêre ruimte in so 'n mate te 'versmoor' het, dat daar vir 'n breër perspektief ten opsigte van die uitbou van die Afrikaanse literatuur min tyd en ruimte was.

\section{3. 'n Majeur-/mineurtaal en die tussenruimtes}

In Suid-Afrika is en was die verhouding tussen Afrikaans en Engels nog altyd kompleks. Dit was deur 'n lang proses (ná Hollandse en Britse bewind) dat Afrikaans uiteindelik as 
selfstandige taal in Suid-Afrika kon ontwikkel en funksioneer. Die institusionalisering van Afrikaans, asook 'n sterk nasionalisme het lank 'n meerderheidstatus of majeurstatus aan die taal in verhouding tot Engels en ander inheemse tale in Suid-Afrika besorg. Binne die wêreldsisteem het Afrikaans egter nog nooit 'n sentrale posisie beklee nie. Die situasie in SuidAfrika sou noodwendig verander met die politieke omwentelinge van die 1990's: Afrikaans het sy dominerende, sentrale posisie ten opsigte van ander tale verloor, en is nou saam met tien ander tale 'n 'amptelike' taal. Engels het gou 'n baie prominente posisie ingeneem op institusionele, sosiopolitieke en kulturele vlak, en beklee 'n sentrale posisie in verhouding tot Afrikaans en die ander inheemse tale in Suid-Afrika. Binne die wêreldsisteem is dit tans hoofsaaklik die aantal sprekers van Afrikaans wat veroorsaak dat Afrikaans baie min literêre kapitaal het en gevolglik beperkte of lae internasionale aansien geniet. Hierteenoor geniet Engels 'n dominante posisie in Suid-Afrika: Engels besit baie literêre kapitaal vanweë sy spesifieke prestige, die historisiteit van die taal, en die aantal tekste wat in hierdie taal geskryf en internasionaal as belangrik geag word. Dit is die gedifferensieerde akkumulasie van kapitaal op groot skaal wat, volgens Heilbron en Sapiro (2007:99), die ongelyke magsverhoudings tussen verskillende nasionale kulture onderlê (wat van kreatiewe veld tot veld varieer), en wat gevolge inhou vir die resepsie van kulturele produkte en hulle funksies en gebruike in 'n gegewe literêre veld.

In die lig van die problematiek van 'n utopiese verenigde literêre sisteem, is nuwe insig nodig om die komplekse realiteit te beskryf wat simplisties as die botsing van twee ruimtes afgemaak sou kon word. Die konsep ruimte (space) is nou verbind met ideologie, en volgens Vidal Claramonte (2012:271), fundamenteel tot hedendaagse vertalers wat in ruimtes werk waar konflik en hibriditeit hand aan hand loop. Hierdie siening van ruimte daag die tradisionele idee uit dat kulture hulleself volgens die kaarte wat ánder vir hulle uitgelê het, handhaaf (ibid:271). Dit is veral die gedagte dat ruimte as metafoor (kan) dien vir onsuiwerheid (in die lig van Douglas (1966) se purity and danger-konsep), en relevant is tot ' $n$ begrip van hoe verskille ervaar word, wat in die geval van Krog van belang is. Vertaling en vertalers word gekonfronteer met ruimte(s), ruimtes wat binne 'n diskoers van globalisering, ruimtes is van die hibridisering ${ }^{6}$ van identiteite, van konfrontasie en andersheid (ibid:272). Die metafoor van onsuiwerheid word hier terselfdertyd gekoppel aan die idee van taal as 'n mineurruimte en die wyse waarop dit binne 'n majeurruimte funksioneer.

Binne die algemene siening van vertaling as 'n handeling van oordrag, sou daar geargumenteer kon word vir 'n genuanseerde mineurbeskouing van vertaling, wat simptomaties is van die spanning wat gedurig heers tussen die plaaslike en die globale, die vreemde en die bekende, veral op 'n kontinent soos Afrika wat sedert koloniale tye met die skynbare aantreklikheid van 'n 'great beyond' moes worstel. Wat nodig is, is om oor die diskoers en die handeling(e) van vertaling te dink in terme van oorgangsruimtes, transitional spaces, of kontaksones - third spaces, aldus Bhabha. Volgens Bhabha (1994) bestaan die vertaler slegs in hierdie tussenruimtes van kulture en tale - die enigste moontlike ruimtes van vertaling. Wanneer sodanige 'blootgestelde' ruimtes tussen tale bestaan, word vertaling 'n middel wat die leser binne die ruimte van 'n ander laat inbeweeg.

\footnotetext{
${ }^{5}$ Ruimte is nie slegs 'n raamwerk nie, maar 'n lewende entiteit/wese wat voortdurend voortstu en ontwikkel, en nooit neutraal is nie (Vidal Claramonte 2012:272).

${ }^{6}$ Kontemporêre kritiese diskoers is op soek na die dieper, gevaarliker betekenis van hibridisering (Vidal Claramonte 2013:275).
} 
Bhabha se siening van kulturele ontmoeting (engagement) of kontak kan toegepas word op die vertaalpraktyk en vertaalruimte, omdat vertaling in wese kulturele oordrag is. In die vertaalkonteks sou dit dus waardevol wees om op daardie momente of prosesse te fokus wat as gevolg van die artikulasie van kulturele verskille geskep word. Hierdie momente verteenwoordig die tussenruimtes, wat op hulle beurt die teelaarde is vir identiteitsvorming (die 'self' word gevorm in reaksie op die identiteit van die 'ander', wat, indien 'n strategie van vervreemding in die vertaalproses gevolg word, in die doelteks neerslag vind), samewerking (tussen die agente in die verskillende kulture), en geskille of weerstand (binne die vertaalruimte word byvoorbeeld 'n mate van konflik geskep deurdat die vertaler doelbewus of onbewus beide bron- en doelkultuur gelyke of ongelyke prominensie gee) (Bhabha 1994:2). ${ }^{7}$ Die vraag wat gevra sou kon word, is hoe die subjek (Krog, of haar tekste) in hierdie tussenruimtes gevorm word; hoe sy haar strategieë van representasie (vertaling) of bemagtiging artikuleer in 'n ruimte waar verskillende gemeenskappe verskillende eise stel, en waar die uitruil van waardes, betekenis of prioriteite nie altyd in samewerking geskied nie maar dikwels antagonisties is teenoor mekaar en tot konflik lei. Dit is dan juis déúr hierdie representasie van 'verskille' waarby die subjek (deur vertaling) betrokke is, veral vanuit die perspektief van die minderheid (minority), dat hibriede kulturele identiteit 'n regmatige plek kan kry.

Bhabha se verwysing na die minderheid, of die mineurhandeling kan gelees word binne Deleuze en Guattari (1987:xiv) se beskouing van die affektiewe potensiaal van 'n literêre werk wat vanuit 'n mineurletterkunde geskep word. Dit gaan derhalwe oor 'n nuwe manier van gebruik in die majeurtaal, "[because it] short-circuits the appeal to a higher, dominant reality - through the 'paper language' [...] that would function from within as a principle of subjectivisation" (Deleuze \& Guattari 1987:xiv). 'n Skrywer (vertaler) binne 'n mineurletterkunde skryf (vertaal) teen die huidige stroom en vanuit 'n linguistiese ruimte (vertaalruimte; third space) wat radikaal van sy of haar voorgangers verskil. Sodanige skrywer/vertaler tree dus op as die inisieerder van 'n nuwe literêre kontinent: ' $n$ kontinent waar lees en skryf nuwe perspektiewe ${ }^{8}$ oopmaak, nuwe gedagtegange inisieer, en waar die spore van verouderde denke oorgeskryf of herskryf word (Deleuze \& Guattari 1987:xiv). In ooreenstemming met een van die kenmerke van 'n mineurletterkunde, naamlik die deterritorialisering van taal, sê Deleuze en Guattari (1987:18):

minor no longer designates specific literatures but the revolutionary conditions for every literature within the heart of what is called great (or established) literature. Even he who has the misfortune of being born in the country of a great literature must write in its language [...] And to do that, finding his own point of underdevelopment, his own patois, his own third world, his own desert.

\footnotetext{
${ }^{7}$ Palmié (2013) benadruk refleksie oor die aard van die 'hibriede' - "How do we know the 'hybrid' - except by the prior assumption that there is something "pure'?" Dit is hier ook belangrik om die konsep te relativeer: "that which is (thought to be) hybrid at any one time and in any one context" (Palmié 2013:465). Die tydstip van hibriditeit (van 'n taal, 'n skrywer, 'n vertaler) is wat van belang is, nie dit wat hibried is nie.

${ }^{8}$ In sosiokulturele terme, presenteer die literêre veld (oftwel die majeurruimte) dit aan elke agent as 'n "space of possibles" (Bourdieu 1993:64), 'n ruimte wat bestaan uit die verhouding tussen die struktuur van die gemiddelde kans om verskeie posisies te beklee, en die disposisies van die agent, oftewel sy of haar subjektiewe basis van persepsie en evaluering van objektiewe kanse.
} 
Die produktiewe kapasiteit van die third space, en die agent(e) wat daarbinne werksaam is, baan die weg vir die konseptualisering van 'n internasionale ${ }^{9}$ kultuur wat die inskripsie en artikulasie van die hibriditeit van kultuur as grondslag het. Die gebruik van die voorvoegsel "inter" of "tussen", is wat Bhabha (1994:56) noem "the cutting edge of translation and negotiation, the inbetween space - that carries the burden of the meaning of culture."

\section{Krog en literêre kapitaal}

In 1996, voor die publikasie van Country of my skull in 1998, ontvang Krog as deel van die SABC-radiospan die Pringle Award vir uitnemendheid in joernalistieke verslaggewing (tydens die WVK) en die Foreign Correspondence Award vir uitstaande joernalistiek (1996). Daarna volg die Sunday Times/Alan Paton Award vir die beste Suid-Afrikaanse niefiksie (1999), die BookData/South African Booksellers' Choice Award (1999), die Hiroshima Foundation for Peace and Culture Award (2000), en die Olive Schreiner-prys vir die beste prosawerk tussen 1998 en 2000 (2001). Hierbenewens word Country of my skull aangewys as een van die top100 boeke deur Afrikane in die twintigste eeu, en dit word deur Suid-Afrikaanse Biblioteke (LIASA) genomineer as die beste boek in tien jaar van demokrasie in Suid-Afrika.

In Oktober 2003, vyf jaar ná die verskyning van Country of my skull, verskyn $A$ change of tongue by Random House South Africa. Twee jaar later in September 2005 verskyn die Afrikaanse weergawe ' $n$ Ander tongval by Tafelberg, 'n drukkersnaam van NB-uitgewers wat tradisioneel Krog se poësie gepubliseer het (Human \& Rousseau en Kwela). Soos in die geval van Country of my skull besit $A$ change of tongue / ' $n$ Ander tongval as produk veel meer as bloot literêre kapitaal; die feit dat die boek aanvanklik in Engels verskyn het, en dit by 'n prominente uitgewer, en daaropvolgend die vertaling in Nederlands, het aanvanklik daartoe bygedra dat $A$ change of tongue kulturele en simboliese kapitaal opgebou het. In die buiteland word die boek aanvanklik gelees vir die transformasie wat dit simboliseer. Die simpatieke gehoor wat Country of my skull internasionaal gehad het, en die bykomende politieke kapitaal wat Krog daardeur gekry het (en steeds het), het die resepsie van $A$ change of tongue heel waarskynlik gunstiger gemaak. Tussen 1998 en 2005 verskyn Krog se vertaling Domein van glas (1999), word Kleur kom nooit alleen nie (2000a) met die RAU-prys vir Skeppende Skryfwerk vereer, Down to my last skin (2000b) met die FNB-Vita Poësieprys, verskyn haar vertaling van Mandela se outobiografie Lang pad na vryheid (2001), word die Kanna-prys vir innoverende denke aan A change of tongue toegeken (2003), word Met woorde soos met kerse (2002a) aangewys as wenner van die Suid-Afrikaanse Vertalersinstituut se driejaarlikse vertaaltoekenning, en verskyn Mamma Medea (2002) asook die sterre sê 'tsau' / the stars say 'tsau' (2004a, 2004b) in Afrikaans en Engels.

Dit lyk asof die politieke agenda wat aanvanklik deel was van Country of my skull se aantrekkingskrag in Suid-Afrika gouer vervang is met 'n groter klem op die literêre kwaliteit daarvan. 'n Mens sou sover kon gaan om te beweer dat Suid-Afrikaanse lesers gouer oor die 'nuutheid' en durf (i.t.v. Krog wat 'n nuwe genre en taal inspan, asook die onderwerp) van die boek gekom het en die teks as letterkundige en vertaalteks begin waardeer het as in Brittanje, waar dit eers sewe jaar ná die eerste uitgawe as hedendaagse fiksie bemark is. 'n Belangrike stuk inligting wat ontbreek by beskikbare data (omslae, titelblad, ens.) oor Country of my skull, is dat die boek 'n Engelse vertaling is van 'n teks, of 'n kombinasie van tekste, nuusverslae, en

\footnotetext{
${ }^{9}$ Internasionale kultuur sou vervang kon word met kosmopolitiese kultuur.
} 
onderhoude wat Krog oorspronklik oorwegend in Afrikaans geskryf het. Hierdie tekste (waarvan sommige oorspronklik wel in Engels geskryf is) is deur Krog in boekvorm aanmekaar gesit en die Afrikaanse gedeeltes van die teks is daarna deur haar seun Andries Samuel in Engels vertaal, waarna Krog dit weer herbewerk het. Krog het dus as 'n herbewerker van die Engelse teks opgetree en nie soseer as die primêre vertaler nie, hoewel sy en haar seun nou saamgewerk het. Ivan Vladislavic het as redigeerder van die Engelse vertaling opgetree. Krog bedank wel haar seun, Andries, wat haar gehelp het met die vertalings (CS 294). Dit is die eerste en enigste aanduiding in die 1998/2002-uitgawe dat dit in die geheel as 'n vertaling geklassifiseer kan word, hoewel Krog ook oorspronklike Engelse teksgedeeltes ingespan het. Sy noem byvoorbeeld dat sy op sekere plekke Stephen Laufer se frasering gebruik het (in Engels), terwyl sy Anton Harber, redakteur van die Mail \& Guardian, bedank wat haar die kans gegee het om in Engels te skryf. Laasgenoemde impliseer dat nie alle bronmateriaal noodwendig vertaal moes word nie (CS 294). Hoe lig of swaar Krog se hand in die Engelse weergawe was, is onduidelik, ook of sy en haar seun saam vertaal het, of hy alleen vertaal het en sy slegs die teks agterna geredigeer het.

Country of my skull verkry internasionale of dalk universele waarde met die publikasie deur Three Rivers Press van Random House in die VSA. Volgens die beskrywing deur Three Rivers Press se 2000-uitgawe is Country of my skull 'n "masterful blend of memoir and reportage [...][Krog's] work fuses a poet's sensibility with a reporter's relentless pursuit of the story", terwyl daar van die 2007-uitgawe gesê word dit is 'n "profound literary account", en op die skutblad van die Suid-Afrikaanse 2002-uitgawe: "Krog's powerful prose lures the reader actively and inventively through a mosaic of insights, impressions, and secret themes." Dit is duidelik uit hierdie beskrywings dat die sterk poëtiese en literêre kwaliteit van Country of my skull erken word, maar ook handig gebruik word vir reklamedoeleindes - dit het met ander woorde sterk emosionele trekkrag.

Met die Engelse mark wat op daardie stadium, 1998, en selfs later, meer ontvanklik was as die Afrikaanse mark vir 'n boek soos Country of my skull, is 'n vertaling in Afrikaans oorbodig en as 'n te groot risiko beskou (Breytenbach 2009). Afrikaanse lesers (Afrikaners) het gemengde gevoelens gehad teenoor die WVK en buitendien het die meeste Afrikaanssprekendes Krog se verslaggewing reeds op Afrikaanse radio en televisie gehoor. Engels was die meer logiese keuse. Nadat Krog op versoek van onder andere Herman de Coninck stukke vir sy tydskrif, Nieuw Wêreldtijdschrift, en vir die Nederlandse pers soos die NRC Handelsblad geskryf het, het sy mettertyd die behoefte ontwikkel om oor die hele proses te skryf; nie net oor die verslae self nie, maar ook haar eie ervaring daarvan (Krog 2007). NB-uitgewers het haar aanbeveel om die geleentheid om in Engels te publiseer te gebruik en Krog het Random House South Africa se aanbod om die boek in Engels te publiseer, aanvaar (Breytenbach 2009). In terme van simboliese produksie was dit in Krog se geval 'n proses waar sy as skrywer literêre en kulturele kapitaal besit het voor die publikasie van die boek. Haar aanstelling in 1993 by Die SuidAfrikaan, asook die artikels wat sy tot en met 1996 vir Anton Harber by die Mail \& Guardian geskryf het, het haar noodwendig 'n sekere disposisie gegee om as politieke verslaggewer by die Suid-Afrikaanse Uitsaaikorporasie (SAUK) te werk. Krog het dus reeds 'n stewige basis binne die Engelse kulturele en literêre veld in Suid-Afrika gehad weens haar betrokkenheid by die WVK, haar artikels in die Engelse pers, en die verskyning van die vertaalde weergawe van Relaas van 'n moord (1995), Account of a murder (1997; vertaal deur Karen Press). Op hierdie punt is dit veilig om te beweer dat Krog se status as Afrikaanse digter nie noodwendig 'n 
belangrike rol gespeel het in die besluit van Random House om haar te nader oor 'n boek oor die WVK nie.

In een van die min sosiologies-teoretiese ondersoeke na Krog se literêre en simboliese kapitaal beweer Garman (2007:1) dat Krog se komplekse verhouding met die media en haar akkumulasie van media-kapitaal 'n belangrike rol gespeel het in die wyse waarop sy 'n unieke stem en voetstuk ontwikkel het in postapartheid Suid-Afrika, waar min (Afrikaner)stemme in 'n openbare domein werklik gehoor word. Reeds as 17-jarige haal Krog die koerant met die publikasie van sommige polities sensitiewe gedigte in 'n skoolkoerant. Met D.J. Opperman se goedkeuring word haar debuutbundel dieselfde jaar (1970) by Human \& Rousseau gepubliseer, waarmee Krog vroeg die Afrikaanse literêre veld betree en haar gevolglik as literêre stem binne die Afrikaanse literêre veld laat geld.

\section{Om aandag op te eis}

Met die plasing van "ma" in Down to my last skin (DLS 12) as tweede gedig ná "my beautiful land" stel Krog ten minste twee aspekte van haar poëtika aan die Engelse leser bekend: nie alleen word die teksaard uitgestip nie ("poem / without fancy punctuation / without words that rhyme / without adjectives / just sommer / a barefoot poem -"), maar ook die omvang van Krog se ma se invloed op haar dogter se skryfwerk:

ma

ma I am writing a poem for you

ek skryf vir jou 'n gedig

without fancy punctuation

sonder fênsie leestekens

without words that rhyme

of woorde wat rym

without adjectives

sonder bywoorde

just sommer

net sommer

a barefoot poem -

'n kaalvoetgedig

because you raise me

want jy maak my groot in jou krom klein handjies

in your small halting hands

you chisel me with your black eyes

jy beitel my met jou swart oë

and pointed words

en spits woorde

you turn your slate head

jy draai jou leiklipkop

you laugh and collapse my tents

jy lag en breek my tente op

but every night you offer me

maar jy offer my elke aand 
to your Lord God

vir jou Here God

your mole-marked ear is my only telephone

jou moesie-oor is my enigste telefoon

your house my only bible

jou huis my enigste bybel

your name my breakwater against life

jou naam my breekwater teen die lewe

\section{I am so sorry ma}

Ek is so jammer mamma

\section{that I am not}

dat ek nie is

what I so much want to be for you

wat ek graag vir jou wil wees nie

(vertaler Karen Press)

In die gedig, wat vertaal is deur Karen Press, word daar verwys na die digter se ma se "halting hands", die manier waarop sy die dogter beitel ("you chisel me"), haar "pointed words", en na haar naam as "my breakwater against life." Op inhoudelike vlak, word die moeder in strofe 2 dus nie noodwendig slegs vereer vir haar bereidheid "om na haar kind te luister, riglyne vir die lewe te gee en teen die lewe te beskerm" (Kannemeyer 1988:361) nie, maar neem 'n mens die bepalende rol waar wat Dot Serfontein as skrywerma in Krog se vroeë ontwikkeling as digter en skrywer gespeel het. In die laaste strofe sou die digter se ma verder ook as metafoor kon dien vir die taalpuriste of letterkundiges aan wie ' $n$ jong, ontluikende digter verantwoording sou moet doen; daarom dat Krog by voorbaat, op die ouderdom van 17, verskoning vra dat sy nie die tipe digter gaan wees wat daar van haar verwag word nie, dat sy grensoorskrydend gaan wees.

Kristeva (1982; 2004:204) noem dat sodanige benadering die verband uitlig tussen die interne dimensie van 'n teks en die eksterne konteks, waarmee uiteindelik die outentiekheid van die skrywende subjek blootgestel word. Die skrywer word 'n "subject in process and a subject on trial. As such the speaking subject is a carnival, a polyphony, forever contradictory and rebellious" (Kristeva 2004:204). Wanneer die onderskeid tussen die subjek en die objek onduidelik is (pseudo-entiteite), vind wat Kristeva noem 'n dialektiese verhouding plaas tussen aantrekking ("attraction") en afkeer ("repulsion"). Die moeder as objek is die eerste slagoffer van die proses van "skorsing" - die moeder word die eerste abjek, eerder as objek in die proses van abjeksie (Kristeva 1982, 2004:206). Wat Kristeva beskryf, is die grondslag van vroue se posisie binne die semiotiese bevryding waartydens mans tekste geskep het wat teen die reëls van konvensionele taal indruis (Jones 1997:371). Binne hierdie denkraamwerk is vroue as moeders die eerste objek van liefde, en van wie die kind geskei word. Op metapoëtikale vlak hou die moeder 'n bedreiging in vir die oorsteek van grense, by Krog, 'n wegbeweeg van die moeder (Afrikaans) na die vader, Engels. ${ }^{10}$ Die semiotiese diskoers is volgens Kristeva (in

\footnotetext{
${ }^{10}$ Verwys na Lacan se "Law of the Father" as draer van taal en kultuur (Lemaire 1977). Van belang hier is die dilemma wat Krog in ' $n$ Ander tongval beskryf, waar die verteller aan die karakter Christina bely dat sy wettig wil wees, wil bestaan, en sy worstel gevolglik met die begeerte om in Engels gelees te word, want "Engels het die deur na die Vader geword" (AT 295), en die vrees dat sy haar gekoloniseerde, Afrikaanse wortels sal verraai of sal uitverkoop. Die 'Vader' verwys hier na erkenning in die Engelse literêre veld in Suid-Afrika en internasionaal.
} 
Jones 1997:371) 'n bloedskandelike verwerping van die simboliese orde deur vroue se bevrydende potensiaal binne die marginale posisie waarin hulle hulle bevind. Om as vrou sosiale, seksuele en simboliese ervarings te hê, is om iets anders te word - 'n subjek-in-wording, 'n subjek-onder-verhoor (ibid:372). Om buite die moederlike beskerming te beweeg, en die simboliese orde van die nuwe ruimte uit te daag, is wat Krog doen.

'n Belangrike vraag wat gevra kan word, is in watter mate Down to my last skin as eerste Engelse digbundel van Krog binne die Engelse literêre (poësie)veld, wat Krog deur die verskyning van die bundel betree het, grensoorskrydend was, soos haar poësie vanaf 1970 binne die Afrikaanse veld grensoorskrydend was. As resensies enigsins 'n aanduiding is, kan gesê word dat Krog se Engelse poësie met voorbehoud ontvang is: "Krog has the guts, or perhaps the protection of fame, to constantly risk absurdity" (De Kock 2000:9). Uit De Kock se resensie wil dit voorkom of Krog die moed en durf het om haar eie styl met oortuiging in Engels te handhaaf, iets wat Engelse digters in Suid-Afrika klaarblyklik nie het nie. Holtzhauzen (2001:6) beskou Krog as 'n uiters suksesvolle digter binne die hele Suid-Afrikaanse literêre veld: "it is by finding the right words and putting them in the right order that Krog succeeds as poet, perhaps without equal on the landscape of South African literature." Rycroft (2000:11) se resensie hang saam met dié van De Kock, as hy Krog se Engelse poësie as eerlik en halstarrig beskryf: "In Antjie Krog's Down to my last skin English-speakers have the opportunity of experiencing the raw and unyielding voice of one of South Africa's most acclaimed poets." Dit lyk of Down to my last skin binne die Engelse literêre veld geïnterpreteer is as verteenwoordigend van Krog se omgaan met sowel die private as die politiese sfeer van die lewe. J.M. Coetzee se hoofkarakter in sy boek Diary of a bad year (Coetzee 2007:199) artikuleer waarskynlik die persepsie van Krog binne die Engelse literêre veld as hy na die "white heat" van Krog se werk verwys: "her capacities as a poet have grown in response to the challenge, refusing to be dwarfed." Hier bespeur 'n mens weer eens 'n moontlike verwysing na (Engelse) digters wat nie dieselfde durf het as Krog wat die oorskryding van grense betref nie, en gevolglik nie die mas opkom binne die Engelse literêre veld nie.

Tog, nege jaar ná die publikasie van Down to my last skin deur Random House SA in 2000, was die publikasiestatus van die bundel steeds aktief, ${ }^{11}$ wat impliseer dat dit genoegsaam deur boekhandelaars aangekoop word en genoegsaam verkoop om voortgaande publikasie te regverdig. Vir 'n Afrikaanse digter om in die Engelse literêre veld sodanige status met 'n vertaalde bundel te bereik, is nie algemeen nie. Met die verskyning van die bundel in 2000, word 'n nuwe Afrikaanse bundel deur Krog, Kleur kom nooit alleen nie, tegelykertyd by Kwela gepubliseer. Dat die publikasie van die twee bundels in dieselfde jaar was, is heel waarskynlik toevallig, maar dit is wel moontlik dat die resepsie van die bundels ' $n$ wedersydse positiewe uitwerking gehad het. Met die FNB Vita-toekenning word Krog se poësie in Engels as ondersoekend en vernuwend bestempel, en die vertalings as "vivid recreations in their own right" ("Vita award for Krog's English word" 2001:21). Die bundel word voorts geloof vir die literêre kwaliteit daarvan, en die akademiese debat wat dit sou ontketen, word ondersteun (Holtzhausen 2001:6). Akademiese debat as sodanig is gesond vir die ontwikkeling van 'n sterk teenwoordigheid van 'n skrywer in enige literêre veld aangesien dit ' $\mathrm{n}$ bevestiging is van belangstelling in die werk en dat daar krities oor die werk gedink word. In dieselfde artikel,

\footnotetext{
Hierdie vrees wat Krog artikuleer, hou verband met die konseptuele gaping tussen die 'inheemse' en die 'uitheemse' as monolinguistiese pole, wat op sy beurt 'n simptoom is van wat Lefevere (1981:76) beskryf as "the Romantic stress on the mother tongue as the primary material for literary creation."

${ }^{11}$ Inligting korrek soos op 30 Maart 2009, Nielsenbookdataonline.
} 
getitel "Krog peels the everyday skin away to bare her poetic soul", word Krog as een van SuidAfrika se groot digters bestempel, en die bundel as 'n "powerful, moving and humbling anthology" (Holtzhausen 2001:6). Cloete (2001:12) noem dat die vertaalde gedigte beter is en varser as feitlik enigiets anders wat op daardie stadium deur Engelssprekende digters in SuidAfrika gepubliseer is. Volgens De Kock (2000:9) is een van die redes hiervoor dat Krog temas of onderwerpe wat Engelssprekende Suid-Afrikaanse digters lank vermy of op oordrewe satiriese of selfvergenoegde wyse hanteer, op 'n eerlike wyse hanteer. Ten spyte van Krog se uitspraak dat Down to my last skin deel is van die Afrikaanse letterkunde, en nie die Engelse letterkunde nie (DLS 6), lyk dit uit die aanvanklike resepsie van die bundel asof Krog relatief moeiteloos die Engelse literêre veld betree het.

\section{Vertaling en/as abjeksie}

Die gedig "nightmare of A Samuel born Krog" (DLS 49) is Krog se vertaling van "visioen van 'n lessenaar" (OB 23) in die vyfdelige gedig "vyf horries van a.e. Samuel (geb. Krog)" in Otters in bronslaai:

the desk is warm and bloody like a newly slaughtered carcass

die lessenaar is warm en bloederig soos 'n pasgeslagte karkas;

from the drawers transparent synovial fluid drips

uit die laaie drup deurskynende sinoviale vog.

the cahir against my back becomes big and pulpy

die stoel teen my rug word groot en pulp;

[...]

my hand falls on the white breath of the page

my hand val op die wit asem van die blaai

an animal with fur on its back

- 'n dier met blink haartjies op die rugkant

the pen becomes a soft hairy nicotine-stained finger

die pen word ' $n$ sagte harige nikotienbruin vinger

the letters it writes listlessly start decomposing at once

die letters wat hy lusteloos skryf, raak los van verrotting

books swell with indignation

boeke swel van verontwaardiging

the typewriter grinds its olivetti teeth

die tikmasjien kners sy olivanti-tande

I write because I am furious

en ek skryf omdat ek woedend is

Die slotreël van die gedig het bekend geword as die klassieke Krog-reël: "ek skryf omdat ek woedend is", wat in haar oeuvre sigbaar word in verse oor die liefde, die natuur, oor die struggle en oor die rouheid van emosies. Die teenwoordigheid van hierdie elemente in Krog se poësie, spreek van wat Hambidge (1996:123) beskou as die taak van die digter as 'n sosiale kommentator. Dit spreek van 'n passie aanwesig in haar werk, wat dikwels ook die inspirasie agter die digproses is. Hierdie passie, asook die element van woede binne haar (die digter se) taak as sosiale kommentator, sluit tot 'n mate aan by Krog se preokkupasie met die konflik tussen estetika en politiek, soos in Lady Anne (1989), en by aspekte soos die idee van 'n 
meerduidige samelewing waarbinne diverse groepe op kreatiewe wyse in interaksie is met mekaar (Viljoen 2009:163).

Die tema 'om die self te skryf', is reeds teenwoordig in Krog se vroegste gedigte en is tekenend van aspekte soos die oorsteek van grense tussen die self (private) en dit wat buite hierdie self lê (openbare/publieke), en, uiteindelik, die herformulering of herskryf van die vrou as skrywer, as digter, as ma, as joernalis, as subjek. As 'dogter' van die Afrikaanse literêre tradisie, het die Afrikaanse literêre veld mettertyd gewoond begin raak aan Krog se woede, haar politieke uitgesprokenheid, haar weerstand teen tradisie, en haar as't ware vir haar politieke, vroulike, poëtiese en linguistiese subjektiwiteit en performativity 'vergewe'. Krog se ontwikkeling as digter in die hibriede ruimte van die interregnum ${ }^{12}$ sou noodwendig 'n rol kon speel in die manier waarop sy vanaf die laat negentigerjare, maar veral vanaf 2000 as vertaler binne 'n ander, nuut gedefinieerde hibriede ruimte sou figureer - as hibriede digter, dus, in 'n ruimte van veelvuldige identiteit. Chapman (1996:413) beweer dat digters tydens die sewentigerjare 'n angstige lojaliteit geopenbaar het teenoor estetisisme, iets wat byvoorbeeld in die tagtigerjare vervang is met ' $\mathrm{n}$ groter mate van politiese betrokkenheid, gebaseer op sosiaal- en literêrteoretiese oorwegings. Dat Krog reeds in 1970 op sewentienjarige ouderdom 'n digstyl geopenbaar het wat tegelyk betrokke poësie was asook 'n openlike poësie wat onverskrokke was in die teenstaan van formaliteit, is noemenswaardig.

Hoewel die fokus in hierdie artikel nie primêr op vroulike liggaamlikheid val nie, is enkele opmerkings nodig om vertaling as ' $\mathrm{n}$ beliggaamde handeling te kontekstualiseer. ${ }^{13}$ Hoewel dit algemeen aanvaar word dat die liggaam 'n belangrike rol speel in die fisiese vorming van die subjek, geniet die liggaam - en die wyses waarop betekenis geheg word daaraan en waarop dit gerepresenteer word - minder aandag wanneer dit by literêre of teksondersoek kom (Grosz 1990:81). Dieselfde geld vir Krog, op wie se werk Kristeva se siening van die liggaam as teks en die teks as liggaam van toepassing is. Volgens Kristeva is die liggaam teenwoordig in die teks deur beskrywings van liggaamsdele en funksies, maar ook in die materialiteit van die teks self, die struktuur van die teks of gedig. Die liggaam van die teks, die semiotiese (betekenis)aspek, bied weerstand teen die idee van closure, dit ontwrig die simboliese, en skep - in die geval van poësie - 'n liggaamlike landskap wat hand aan hand loop met die liggaamlikheid van die verwysingsveld daarvan (Kristeva 1986:120). Die skrywer word dus deel van die teks, bewoon (inhabit) die teks en word gevolglik ook deel van die artikulasies en ritmes van die teks.

Die gedigte "dit is waar" / "it is true" (VS 12 / BB 12) verbeeld iets van die liggaamlike en tekstuele landskap van die gedig:

it is true that this landscape will

dit is waar dat die landskap sonder

continue to exist without me the trees

\footnotetext{
${ }^{12}$ Die tydperk 1970-1995 in Suid-Afrika, "the time when the old order was dying and the new struggled to be born" (Chapman 1996:329); "between two identities, one known and discarded, the other unknown and undetermined [...] it is a place of shifting ground" (Gordimer in Chapman 1996:329).

${ }^{13}$ Vergelyk Grosz (1994), Moi (1999) en Young (2005) se standpunte oor beliggaamde subjektiwiteit. Vergelyk ook Conradie (1996), Beukes (1999), Visagie (1999), Crous (2002), Nel (2008) en Viljoen (2009) vir besprekings van liggaamlikheid in Krog se poësie. Wat die psigoanalitiese betref, word slegs Kristeva by hierdie bespreking betrek, hoewel Lacan en Freud se werk 'n sterk basis gevorm het vir haar teorieë.
} 
my sal voortbestaan die bome wat that make me adore the earth the plains my die aarde maak bemin die vlaktes that sweep into seams of light-lipped wat my saamvee in vaandels los water that mirrors the nearest lippige lig die water wat die seams of touch the moon living nabyste staat van aanraking weerspieel die maan stort agteroor in off a stipend of new born stars it is true that it will continue to exist 'n stipendium pasgebore sterre dit is waar dat dit sal aangaan

it is true that I saw three women dit is waar dat ek drie vrouens kaal naked on the beach at Marseilles their op die strand van Marseilles gesien het bodies like three bags of wrinkles their hair hulle lywe drie sakke plooie

like tissues in the wind. with short steps they hulle haartjies waai soos tissues in die wind met kort stappies stap hulle padded into the water their breasts wrinkle-less forming a halo of flesh of steaming risen die water in hulle borste is plooiloos 'n stralekrans stomende breasts blushing into their nipples it is uitgerysde borste blosend tot in die tepels dit is waar dat ek true that I couldn't keep my eyes off them my oё daarvan nie kon afhou nie $[\ldots]$ as of late I stare intensely at old people how dit is waar dat ek begin om ou mense intensief te bekyk they put their feet down or wear their hair that I hoe hulle hul voete neersit hul hare kam dat ek my ö̈

lay my eyes desperately on young skin and fluent verhonger neerlê op jong velle bodies it is true that I'm on the brink of an abyss dit is waar dat ek op ' $n$ afgrond staan

Die inhoud van Verweerskrif/Body bereft sluit aan by die abjekte: 
It is something rejected from which one does not part, from which one does not protect oneself as from an object. [...] It is thus not lack of cleanliness or health that causes abjection but what disturbs identity, system, order. What does not respect borders, positions, rules. The in-between, the ambiguous, the composite. $[\ldots]$ a terror that dissembles, a hatred that smiles, a passion that uses the body for barter. (Kristeva 1982:4)

Kristeva se beskrywing moet in die lig gesien word van dít wat verskuil is binne abjeksie, naamlik 'n verset teen 'n bedreiging - "a threat that seems to emanate from an exorbitant outside or inside, ejected beyond the scope of the possible, the tolerable, the thinkable. It lies there, quite close, but it cannot be assimilated. It beseeches, worries, and fascinates desire" (Kristeva 1982:1).

Wanneer daar in 'n teks (soos ook in film of ander mediavorms) van die abjekte - dit wat uitgewerp of verwerp word - gebruik gemaak word, word die self waaraan die mens vashou onder andere as onstabiel uitgebeeld, en word dit wat Kristeva (in Mansfield 2000:83) beskryf as die grens tussen die binneste en die buitenste, en tussen dit wat as skoon en gepas (in liggaamlike terme) hanteer word, afgebreek. Wat gebeur is dat dinge ${ }^{14}$ soos urine, defekasie, menstruele bloed, semen, braaksel, die skoon liggaam, maar veral ook die mens se bewussyn van individuele identiteit en sekuriteit, bedreig (Mansfield 2000:83). Hierdie objekte wat abjeksie veroorsaak, lei daartoe dat die liggaam met dáárdie oppervlaktes, openinge, gapings (wat ook later seksuele prikkelareas word), geassosieer word - die mond, oë, anus, ore, geslagsdele (Grosz 1990:88). Volgens Lacan (in Grosz 1990:88) is alle seksorgane en prikkelareas in die vorm van 'n rand ("rim"), wat die ruimte uitmaak tussen twee liggaamlike oppervlaktes - 'n tussenruimte tussen die binneste en buitenste liggaam. Hierdie liggaamlike ruimtes funksioneer as drempels tussen dit wat binne-in die liggaam is, met ander woorde deel van die subjek, en dit wat buite is, met ander woorde 'n objek vir die subjek. Die drempels (van taal: "nuwe territory poetic", "pis", "kak"; en inhoud) word onder andere uitgebeeld in Krog se "toiletgedig" (G 15) / "toilet poem" (DLS 54; gedeeltelik aangehaal):

things of course about which one would never write a poem

dinge natuurlik waaroor 'n mens nooit 'n gedig sou skryf nie

force their way into the territory of poetic themes

dring in die nuwe territory poetic temas binne

$[\ldots]$

I piss shuddering rigid half squatting

pis ek rillend verstard effens hurkend

between my legs

tussen my bene deur

into a toilet bowl heaped halfway up

in 'n toiletbak tot in die helfte opgehoop

with at least four different colours of shit

met minstens vier verskillende kleure kak

\footnotetext{
${ }^{14}$ Ek gebruik met opset die woord "dinge" omdat dit tegelyk na die tasbare en die nietasbare verwys - dit is nie noodwendig objekte nie, ook nie elemente nie. Kristeva noem dit "physical flows" of "bodily refuse" in die liggaamlike konteks (Mansfield 2000:83).
} 
Die aversie wat die leser byvoorbeeld ervaar in 'n gedig soos "toiletgedig", spreek van 'n abstrakte proses van teenstrydigheid, onsekerheid en 'n besoedeling van die binneste wat alle orde, betekenis, waarheid ontwrig (Mansfield 2000:85). Krog berei die leser in die eerste reël voor op dit wat gaan volg, en sy sluit die gedig op 'n banale hoogtepunt af met "elke senupunt van weersin orent om mal te word / as maar net 'n enkele druppel op teen my sou spat." Die teenstrydigheid lê daarin dat die subjek in die gedig self besig is om 'n abjekte aksie uit te voer, maar 'n intense weersin ervaar oor die gevaar wat in die laaste twee reëls uitgespel word. Die leser lees hierdie teenstrydigheid raak en herken dit in hom- of haarself en dit is op hierdie punt waarop sy of haar orde en bekende waarheid ontwrig word. Dieselfde geld onsekerheid en veral die besoedeling van die binneste - die vreedsaamheid met die bekende orde, die veilige ruimte van denke en gevoelens word ontwrig.

Volgens Viljoen (2009:191) hanteer Krog die liggaam as tematiese gegewe sterk konvensioneel in veral haar eerste vier bundels, en word daar eers vanaf die vyfde bundel, Otters in bronslaai (1981) beweeg na groteske, monsteragtige en abjekte voorstellings. Krog gebruik "die liggaam in beeldende verbinding met ander entiteite soos byvoorbeeld die poësie en die landskap" (Viljoen 2009:192), en in werke soos Country of my skull en Kleur kom nooit alleen nie word ook die land as liggaam gesien. Soos in die vorige afdeling aangedui, beeld Krog telkens ook die maak van poësie uit as 'n proses wat in die liggaam ontstaan (vergelyk "Digter wordende" en "first sign of life" oor die ongebore fetus), en besin sy in haar poësie oor die problematiek van skryf oor die liggaam, sodat sy voortdurend sekere grense, veral die grense van genres waarin sy skryf, verskuif (vergelyk Viljoen 2009:192). In Down to my last skin, skryf Krog aan die Engelse leser:

you moved in me today

...

like a poem you began without my knowing

a coupling of image and sound

with an umbilical cord to life veined through my blood

after weeks swollen into a gesture of word and vertebrae

a verse trembling this morning into wanting to be written (DLS:35)

en,

to awake one morning into sound

with the antennae of vowel and consonant and diphthong

to calibrate with delicate care the subtlest

movement of light and loss in sound

$\ldots$

the poet writes poetry with her tongue

yes, she breathes deeply with her ear (DLS:59).

In die lig van 'n oorskryding of verskuiwing van grense, ${ }^{15}$ en in die lig van die teenwoordigheid van die abjekte in Krog se poësie, is die volgende twee aanhalings relevant: "Transgression is associated with the sacred, the moment of rupture when the excluded element that is forbidden by the taboo, is brought into focus" (Richardson 1998:51), en "[t]ransgression does not deny

\footnotetext{
${ }^{15}$ Volgens Viljoen (2009:205) oorskry Krog die grense wat verband hou met poëtiese dekorum en korrektheid in die gedig deur haar vermenging van taal asook die gebruik van kragwoorde soos "pis" en "kak".
} 
the taboo but transcends and completes it" (Bataille in Richardson 1998:55). ${ }^{16}$ Volgens Kristeva (1982:207) is alle literatuur ${ }^{17}$ waarskynlik ' $n$ vorm van die apokalips - die laaste groot oordeel - deurdat dit geleë is op 'n baie brose grens waar identiteite (subjek/objek, ens.) nie bestaan nie of net-net bestaan: dit is dubbel, wasig, heterogeen, dierlik, gemetamorfoseer, gewysig, abjek. Hierdie tipe literatuur sou ook as 'n mineuraktiwiteit binne 'n gegewe kultuur kon funksioneer, 'n mineurletterkunde wat ontwrig en subverteer. Dit is in werklikheid 'n ontsyfering van die mens se worsteling en krisisse, sy mees intieme en veelseggende apokalips. Die vraag word gevra: "Does one write under any other condition than being possessed by abjection, in an indefinite catharsis?" (Kristeva 1982:208).

In die gedig "on my behalf" (BB 19) word die Engelse leser wat nie noodwendig vertroud is met Krog se poëtika nie, bekendgestel aan dit waarmee sy haar as digter, politieke aktivis, skrywer, ma, huisvrou en vrou tot op hede besig gehou het - dit wat die onderliggende dryfveer was agter die digproses. Hoewel die gedig 'n vertaling is van "namens myself" (V 19), waar die Afrikaanse leser met 'n soortgelyke "belydenis" te make het, is die herdigting van die gedig in Engels in Body bereft belangrik in die konteks van dit waarmee Krog haar voortaan as digter in Afrikaans en Engels gaan besig hou - hoe sy 'n meer beliggaamde digter gaan wees, hoe die politiek van skuld, verantwoordelikheid, gemarginaliseerdheid, identiteit minder belangrik raak in die aangesig van ouderdom en die onvermydelikheid van die dood:

i no longer need to approach anybody on someone's behalf

namens niemand hoef ek iets meer te benader nie

i no longer need to be accountable for others

namens niemand hoef ek meer verantwoording

or to ask forgiveness on behalf of those who know no guilt

te doen of om vergifnis te vra nie

i no longer need to put anybody's marginalized

niemand se gemarginaliseerde perspektief

perspective on the table or imagine

hoef ek meer op die tafel te plaas nie

myself into the skin of another

of my in ander se vel te verbeel nie

because the first forays of death have arrived

die eerste voorhoedes van die dood

and the body slips like sand through

het opgedaag en die liggaam gly soos sand

the fingers. apathy neutralises the senses

deur die vingers. apatie neutraliseer die sintuie

as survival deploys its brutal forces. one gets cut

oorlewing ontplooi soos ' $n$ woestaard en sny

off from others and becomes more and more

jou af van ander sodat jy al hoe meer vertroud

familiar with the complete inward-turning of death -

raak met die na-binne-gedraaidheid van die dood

\footnotetext{
${ }^{16}$ Oor die onderwerp van die onreine en die taboe, vergelyk ook Douglas (1966). Wat die karnavaleske en die groteske liggaam betref, vergelyk Bakhtin (1984), veral sy bevraagtekening van die grense tussen die amptelike en nieamptelike sfere in die samelewing, en die rol daarvan in sosiale transformasie.

${ }^{17}$ Kafka, Sartre, Bataille, Baudelaire word byvoorbeeld genoem.
} 
drawer after drawer you are being emptied out

laai vir laai word jy leeggemaak

until only your empty inside moves your emptiness about ${ }^{18}$

tot net nog die leë binnekant jou raak

Soos Viljoen beweer, is Afrikaanse lesers reeds vanaf Otters in bronslaai blootgestel en as't ware "opgevoed" nie net in die outobiografiese element in Krog se poësie nie, ${ }^{19}$ maar ook die liggaamlikheid daarvan, die abjekte element daarvan (Hambidge 2009). Met die verskyning van Verweerskrif / Body bereft was die polemiek wat rondom die voorblad en inhoud van die bundel ontstaan het, dus verrassend, maar terselfdertyd te verwagte. Gegewe die geweldig intieme wyse waarop daar met ouderdom asook die verwering van die liggaam omgegaan word, en die algemene opvatting dat dit die mees eksplisiete voorblad van 'n Krog-bundel tot op hede is, ${ }^{20}$ is dit te verstane dat die gemiddelde leser van Afrikaanse poësie heel waarskynlik ongemaklik sou voel en op grond van morele oortuigings beswaar sou maak. Die grensoorskryding, oftewel die "visuele taboe-deurbreking" (Van Vuuren 2006:9) in hierdie geval, het, soos in die geval van byvoorbeeld "toiletgedig", "die effek om die leser te laat gril én lag, maar dit is ook 'n manier waarop [Krog] die ruimte vir vroulike liggaamlikheid binne die Suid-Afrikaanse samelewing met sy streng reëls betreffende vroulike liggaamlike decorum uitbrei" (Van Vuuren 2006:9), of te bowe kom, om aan te sluit by Bataille (in Richardson 1998:55).

Spies (2006:9) beskryf Verweerskrif - en veral die voorbladfoto - as "afstootlik", en verklaar dat dit vir haar gaan oor die "blootstelling van die ou liggaam aan die openbare oog." 21 Sy gaan verder deur te sê "[of] ons dit nou wil erken of nie, is skoonheid in dié verband nie in die aanskouersoog nie, maar in die jong liggaam. [...] Die bundel en die reaksies daarop het my weer laat besef in watter mate Afrikaanstalige lesers en kritici aan kulturele geheueverlies ly, met as onderdeel die ignorering van die tradisie van die Afrikaanse poësie" (Spies 2006:9). Wat Spies deur hierdie veroordeling bevestig, is in die eerste plek die manier waarop die abjekte ontvang word en gevolglik verwerp word, in die tweede plek hoe die jonger liggaam steeds as die volmaakte, ongeskonde ideaal van 'n vroulike liggaam voorgehou word (hoe die stem van die menopousale vrou gevrees en ontken word, vergelyk Tamara Slayton in BB 21, V 21), ${ }^{22}$ en derdens die ambivalensie in die hunkering of verwagting na "direkte segging" (vergelyk Eliot se "objective correlative", soos aangehaal in Spies 2006:9), maar die afkeer daarin en die implisiete versugting na teks en beeld wat grense, posisies en reëls respekteer (met ander woorde die teenpool van die abjekte).

\footnotetext{
${ }^{18}$ Oor die "I" as subjektiwiteit in die gedig kan 'n afsonderlike studie gedoen word, veral oor die verskuiwing in die gedig van die ek-verteller na die derdepersoonsverteller en die objektiwiteit wat intree op dieselfde moment as wat die liggaam op intiemer wyse ervaar word.

${ }^{19}$ In Krog se oeuvre gaan die spreker deur die ervarings van moederskap, menopouse en veroudering, en worstel sy met die wyse waarop die historiese, sosiale en politieke deur die liggaam geartikuleer word, terwyl in haar latere bundels 'n element van verset intree teen oorheersing van die man en die familie (Viljoen 2009:201).

${ }^{20}$ Dit is die eerste bundel van Krog waar sy baie nou betrokke was by die keuse van die voorblad.

${ }^{21}$ Vergelyk Sontag (2003) vir 'n bespreking van die foto as uitbeelding van pyn. Volgens Sontag is foto's 'n objektiewe rekord asook persoonlike getuienis, sowel 'n getroue weergawe of transkripsie van 'n werklike gebeurtenis as 'n interpretasie van daardie werklikheid.

${ }^{22}$ Vergelyk Dumas, Laberge en Straka (2005) se sosiokulturele studie oor liggaamlike estetika en die agehabitus van ouer vroue.
} 
'n Belangrike punt wat die tradisie van die Afrikaanse poësie betref, is dat Krog in haar werk met sowel die manlike tradisie in Afrikaans as met haar "literêre moeders" in gesprek tree, en dat sy, soos Viljoen beweer, wel deeglik veral Eybers ("die grootste digteres" (bron), "my classy heldin" (bron)), se tradisie aanvanklik voortsit, maar dan ook elders aansluiting soek soos by Erica Jong (Hambidge 2009). Krog identifiseer aanvanklik ook met Jonker as literêre voorganger, maar breek uiteindelik weg namate die verhouding tussen die persoonlike en die openbare en die politieke meer ambivalent raak. In Verweerskrif / Body bereft put Krog uit veel meer as net die Afrikaanse tradisie: afgesien van digters soos Amichai, Gerard Manley Hopkins, Hugo Claus, Kopland, Paul Celan, gee sy vernaam erkenning aan Sharon Olds, ${ }^{23}$ Adrienne Rich $^{24}$ en die werk van Tamara Slayton, ${ }^{25}$ Anne Sexton, en aan ouerwordende vroue in die algemeen.

Volgens De Lange (2006:4) skryf Krog haar in Verweerskrif nogmaals los van die kanon, en getuig die taalgebruik van 'n groter weerloosheid, 'n nog feller direktheid en kruheid as in vorige bundels. In teenstelling met Spies beskou De Lange die bundel as vernuwend deurdat Krog vreesloos waag en daardeur nooit vir alle lesers aanvaarbaar of veilig skryf nie, 'n houding waarvan die basis in Dogter van Jefta gelê is wat haar grensoorskrydenheid (vergelyk "Ma") en haar verhouding met haar literêre moeders betref (Hambidge 2009; Viljoen 2009). Dit eggo op sy beurt Olds se benadering waar sy die liggaam en liggaamsdele eksplisiet benoem sonder om in ag te neem wat die leser as betaamlik of kuis beskou. Dit is waarskynlik die sterk feministiese diskoers in die bundel wat skerp reaksie uitgelok het, nie net van Afrikaanse kritici nie, maar ook vanuit Engelse literêre kringe, die "hekwagters van die Engelse taal", soos Krog dit beskryf (Brümmer 2006:15). Sowel die Afrikaanse as Engelse bundel het enkele maande ná die plagiaatdebakel wat deur Stephen Watson aangevoor is verskyn, en 'n mens het verwag dat Krog weerloos sou staan tydens die onmiddellike resepsie van veral Body bereft. In haar resensie van Breytenbach se bundel Veil of footsteps (2008), noem Sampson (2008) Breytenbach die Groot Skrywer, en verklaar, "[h]e is not at home in English. There is the feeling that he is writing with false teeth." Dieselfde sentiment word gelug deur die hekwagters

\footnotetext{
23 'Is there anything that shouldn't or can't be written about in a poem? What has never been written about in a poem?" vra Olds. Olds se poësie getuig van eksplisiete beelde en taal wat sosiaal afgedwingde stiltes oorskry en 'n "erotics of family love and pain" verbeeld. "[t]he point here is that the poet will not shirk the direct confrontation with the body; indeed, Olds often names the body and its parts with an explicitness far beyond any decorous concern with the reader's sense of modesty. But by doing so she disarms the words as inherited metaphors themselves, metaphors that have phallocentrically created special 'dirty' vocabularies for the private use of men, or just as exclusively, clinical vocabularies for the use of controlling medical figures. Both special languages have to do with the tradition of articulate male power over the mute female body; Olds reclaims both the power to speak for her own body and, with a delightful voluptuous arrogance, usurps the descriptive role as well. She traces bodies slowly and deliberately with her tongue: it is a gesture in which one feels the generosity of a lover, the inner necessity of a mother animal, and the conscious aestheticism of the artist" (Kahn g.d.).

24 "Rich's poetry has clearly recorded, imagined, and forecast her personal and political journeys with searing power. In 1956, she began dating her poems to underscore their existence within a context, and to argue against the idea that poetry existed separately from the poet's life. [...]Intimately connected with this struggle for empowerment and action is the deepening of her determination "to write directly and overtly as a woman, out of a woman's body and experience.' In the poem "Tear Gas," she asserts 'The will to change begins in the body not in the mind / My politics is in my body"' (Pope g.d.).

${ }^{25}$ Slayton word aangehaal aan die begin van "leave me a lonely began" (V 21 / BB 21): "the voice of the menopausal woman is feared and denied. She has been made invisible or encouraged to remain forever young..." Slayton was die stigter en direkteur van die Menstrual Health Foundation in Sebastopol, Kalifornië, en aktief betrokke by die bewusmaking by vroue van hulle liggaamlikheid en seksualiteit tydens verskillende lewensfases. Die volgende aanhaling is gepas in die konteks van Krog se bundel: "We design so much of the way we live our lives - the compulsive consumerism, the compulsive relationships - out of a profound cultural fear of death" (West g.d.).
} 
van Engels, soos Krog na hulle verwys, in die resepsie van haar werk (Brümmer 2006:15). Hierdie sentimente bewys, in kort, die beginsel van 'n mineurgebruik van taal, oftewel die 'geheim' daarvan, naamlik dat die majeurtaal en -leser 'n vreemdeling voel in sy/haar eie taal (Deleuze \& Guattari 1987:48). Dit is dus nie slegs Breytenbach of Krog wat nie tuis is in Engels nie, maar die majeurtaal wat nie tuis voel in sy eie vel nie; die leser wat met kunstande lees.

Stephen Watson se aanklag teen Krog in New Contrast, waarin dit duidelik blyk dat sy aanval nie slegs oor plagiaat per se gaan nie, maar veral ook oor 'n Afrikaanse digter wat in Engels durf publiseer. As rolspeler (direkteur van die tydskrif, akademikus by 'n Engelse universiteit, gepubliseerde digter in Engels) het Watson 'n bepaalde invloed gehad op die manier waarop Krog ná die verskyning van die artikel beskou sou word. Watson (2005:48) plaas Krog binne die plaaslike buiteliterêre tradisie van plagiaat ${ }^{26}$ en impliseer dat sy nie deel genoem kan word van die Afrikaanse en nog minder die Engelse tradisie nie. Afgesien van sy kritiek op haar as digter, trek hy Krog se loopbaan as skrywer in twyfel met sy verwysing na haar gebruik van Hughes se konsep mite in Country of my skull. Weer eens wonder 'n mens hier oor die redes ágter die kritiek: Watson vergelyk Krog met Eliot se intelligente gevoeligheid. Sy verwysing na Eliot is waarskynlik nie toevallig nie. Krog sê immers in A change of tongue (CT 271), "I do not have T.S. Eliot or Philip Larkin in my bones.” Die kritiek op Krog blyk dus eerder op die vlak van haar posisie in die literêre veld te lê, maar spesifiek die teenwoordigheid van 'n tradisioneel Afrikaanse skrywer binne die Engelse literêre veld waar die hekwagters waarskynlik feller optree teenoor Krog as wat binne die Afrikaanse literêre veld gebeur. Die ironie, sê Watson (2005:61), is dat Krog hierdie 'wandaad' van plagiaat pleeg te midde van haar status in Suid-Afrika. Wat presies Watson met Krog se status in Suid-Afrika bedoel, is onduidelik, veral in die lig van sy opmerking teenoor Verstraete (2006:79): "I just think of her as a housewife from Kroonstad masquerading as Joan of Arc. So I didn't have a sense of her as a cultural icon." In dieselfde onderhoud (Verstraete 2006:79), beskryf Watson Country of my skull as "another bad and appropriative piece of work. [...] There must have been something else going on in the whole issue for people to have gone so 'bedonnerd' about it ."

Dieselfde tipe scenario het inderdaad hier afgespeel as in die geval van Down to my last skin en the stars say 'tsau'27 se resepsie binne Engelse literêre kringe. Stephen Gray (2006) se fel kritiek op Body bereft is veral simptomaties van die punt wat die bundel wil maak, naamlik dat die gemeenskap wegskram van dit wat die orde versteur (by name Krog as Afrikaanse digter binne die Engelse literêre veld), en op 'n meer direkte vlak die wyse waarop die gemeenskap ouer vroue en die oudwordproses misken (Kennedy 2006:2). Gray (2006) vra hoe goed Krog se tweede taal, Engels, is, en of haar waagstuk om in Engels te publiseer geregverdig kan word. Hy noem onder andere Krog se selfvertaling van die gedigte, "transliteration", wat hy op sy beurt regverdig deur te noem dat daar ongeveer 500 onakkurate vertalings asook talle "poeticisms" is, ${ }^{28}$ en te verklaar dat "such private ache confessions" in die Engelstalige literatuur reeds met Sylvia Plath se dood begrawe is. Deur Plath in die argument in te bring, verwys Gray dus na die wêreldliteratuur, en nie spesifiek na Suid-Afrikaanse Engelse literatuur nie. Die standaard vir Krog se posisionering binne die Engelse literêre veld word inderdaad hoog gestel.

\footnotetext{
${ }^{26}$ Watson verwys na die joernalis en skrywer Darrell Bristow-Bovey wat van plagiaat aangekla is. Volgens Watson staan hy en Pamela Jooste buite die literêre tradisie of die literêre veld. Watson groepeer Krog by hierdie tradisie, hoewel sy duidelik binne 'n literêre tradisie (hetsy Afrikaans of Engels) staan as digter en skrywer.

${ }^{27}$ Vergelyk Vosloo (2010).

${ }^{28} \mathrm{Dit}$ is onduidelik waarna Gray presies verwys.
} 
Een van die belangrikste aspekte wat na vore kom uit Gray se resensie, is die aandag wat Krog as Afrikaanse skrywer van die Engelse literêre veld opeis. Krog is geen nuweling op die toneel nie; soos aangedui, is haar stem binne die Engelse literêre veld in Suid-Afrika en internasionaal reeds met Country of my skull en A change of tongue as belangrik geag, waarna sy verdere literêre kapitaal (meestal in Suid-Afrika) bekom het met die publikasie van Down to my last skin. Afgesien van die plagiaataantygings van Watson, wil dit voorkom asof haar groeiende status as Afrikaans-Engelse skrywer 'n bedreiging inhou vir die bestaande orde van die Engelse letterkunde in Suid-Afrika spesifiek. Dit is nie toevallig nie dat Gray (2006) opmerk "[n]ow we are to believe Krog just sommer writes in both the old official languages [...] Krog's poetry represents the end of once-brave Afrikaans literature as such, as it collapses into pretension and incompetence." Twee dinge val op in Gray se kritiek: sy gebruik van die Afrikaanse woord "sommer", wat waarskynlik doelbewus was om ironies te wees, en sy aanklag teen die Afrikaanse literatuur in die algemeen. Vir Gray gaan dit dus nie soseer daaroor dat dit Krog is wat in Engels skryf nie, maar dat dit 'n Afrikáánse digter is wat dit waag om in Engels te publiseer. Gray se resensie sou noodwendig 'n rol speel in die manier waarop die Engelse publiek Body bereft ontvang. Hiermee saam is dit belangrik om te noem dat Engelse lesers wat vir die eerste keer Krog se poësie in Engelse vertaling lees, dit nie noodwendig kan waardeer binne dieselfde konteks as wat dit aanvanklik geskryf is nie, omdat hulle nie haar volle oeuvre en die tematiese stramiene ken nie: die doelbewuste Afrikaanse ondertoon in Engels, die teenwoordigheid van die abjekte in haar werk en die feministiese inslag.

Op dieselfde wyse waarop Krog se habitus as skrywer en vertaler uit haar werk blyk, is die persepsies en verbandhoudende reaksies op die verskyning van 'n bundel soos Verweerskrif / Body bereft 'n gevolg van sosiale gedrag wat in die konteks van 'n gemeenskap van disposisies ontstaan (Bourdieu 1977:35). Die leser, resensent, kritikus, teoretikus tap uit 'n hele spektrum beskikbare strategieë, en kies (op onbewuste vlak) uit 'n spektrum moontlike uitkomste wat die wêreldbeeld in ' $\mathrm{n}$ bepaalde sosiale en kulturele konteks, en op 'n gegewe historiese moment, hulle toelaat om te sien. Die leser is nie bewus daarvan dat sy of haar keuse van optrede op hierdie manier 'beperk' is nie, en die keuse van optrede word dus ervaar as die onvermydelike omstandighede van gedrag. Sy of haar verhouding tot hierdie keuses word ook nie in 'n kulturele, ideologiese of godsdienstige konteks ervaar nie, maar as bloot praktiese oorwegings gesien. Soos in die geval van die skrywer, ontstaan ook die leser se strategieë dus uit 'n kollektiewe en dinamiese (veranderende) 'geskiedenis' van moontlike gedrag - "systems of durable, transposable dispositions", oftewel habitus (Bourdieu 1977:72). Hierdie aspek van die resepsie van 'n literêre werk is iets wat relatief min aandag geniet wanneer dit kom by die beoordeling of selfs interpretasie van sodanige resepsies. Net soos wat die habitus van die skrywer of digter of vertaler die kompleksiteit en ambivalente aard van sosiale en kulturele gedrag verklaar, is die vryheid in gedrag en optrede van die leser in 'n sekere sin voorbestem, met inagneming van die (relatief groot) ruimte vir spontaneïteit wat daar wel bestaan.

Op soortgelyke wyse as wat Kristeva van die abjekte as 'n tussenruimte praat, kan die vertaalhandeling vanuit die mineur- in die majeurtaal - met ' $n$ mineuraanwending van die majeurtaal - gesien word as 'n abjekte handeling. Krog word daarvan beskuldig dat sy niestandaard Engels ${ }^{29}$ gebruik: woorde soos "filigree", "unbeknownst", "wisps", "tintinnabulous bliss" en "nimbular mush" gee volgens Gray (2006) aan (Engelse) poësie 'n slegte naam. Hy sê

\footnotetext{
29 'n Mens sou kon praat van 'n deterritorialisering van Engels in hierdie geval: na aanleiding van Gray (2006) se kommentaar blyk Krog haar eie "point of underdevelopment, [her] own patois, [her] own third world, [her] own desert" in Body bereft te gevind het.
} 
voorts haar Afrikaanse ondertoon is onpoëties en onaanvaarbaar, en noem "drybaked cunt", "my downsitting and mine uprising" uit Body bereft as voorbeeld. Met die benadering om die Afrikaanse onderbou in Engelse vertaling te behou, hou Krog die kontaksone tussen Afrikaans en Engels lewendig as 'n plek van veelvuldige artikulasies, waar taal en die aanwending daarvan nie as 'n grens hoef te funksioneer nie. Krog gaan nie noodwendig op 'n bewuste vlak met haar werk om asof sy (en die werk) haarself in 'n oorgangsruimte of hibriede ruimte wil posisioneer nie. Die rede hiervoor het waarskynlik te doen met die feit dat daar tradisioneel onder Afrikaanse skrywers (en Afrikaanse uitgewers) die persepsie bestaan dat hulle as randfigure in die Suid-Afrikaanse Engelse literêre veld beskou word. Hoewel Krog hierdie persepsie verwoord wanneer sy aan Brümmer (2006) bely dat sy al die jare uitgelos is toe sy net in Afrikaans geskryf het, maar haar nou 'n "randfiguur" voel binne die Engelse literêre veld (en selfs daarbuite), is dit waarskynlik veilig om te beweer dat Krog eerder binne 'n hibriede ruimte in die Engelse literêre veld staan. Hierdie tussenruimte of kontaksone, 'n "in-between", 'n third space, is 'n ongemaklike, ontblote ruimte wat simptomaties is van die spanning wat heers tussen twee meer definitiewe ruimtes uit die oogpunt van die Engelse leser: die een bekend (Engels), die ander vreemd (Afrikaans), die een plaaslik en die ander globaal, intimiderend, gelykmakend, universeel.

Met die teenwoordigheid van 'n habitus van die abjekte in Krog se poësie in die algemeen, en in Verweerskrif in die besonder, wend sy taal op 'n mineurwyse aan in Down to my last skin en Body bereft. Krog gebruik skatologiese, plat taal, sy oortree taboes in verband met menstruasie, sy span 'n gedronge taal en hortende ritme in, sy stel die stem van die ander, die kultuurvreemde voorop, die klipperigheid van die landskap word 'n simbool van haar taalkundige gebrek of onvermoë om haar volledig uit te druk in die niemoedertaal (en moedertaal). In Lady Anne in "'n Gedig oor skuld" (LA 100) word daar 'voorbrand' gemaak (hoewel op 'n onbewuste (habitus)vlak) vir haar eie oorgang na 'n tweetalige skrywer of vertaler. 'n Mens sou in die lig van haar ambivalente posisie binne die Engelse literêre veld die woord "Afrikaans" met "Engels" kon vervang (gedeeltelik aangehaal):

\section{$[\ldots]$}

wil die digter 'n gedig skryf

verby die drag geraamtes

van almal wat mank en [Engels] is

maar die tong sal anders moet lê:

bevry die allerwoordste woord deur vers

wat wil klapwiek namekaar en nuut

die gedig sal wys hoe

woord in hierdie landskap waar word

$[\ldots]$

Die gedig impliseer op 'n ander vlak ook die "wording" of becoming as skrywer/vertaler waaroor Krog in "Digter wordende" / "poet becoming" skryf, maar in 'n risomiese konteks: die wordende-skrywer of die wordende-vertaler. Volgens Deleuze en Guattari (Mansfield 2000:145) is die tema van wording 'n belangrike aspek:

it sees the life of things in terms of an ever-changing and everrenewed movement out of fixed forms into new possibilities. "The rhizome operates by variation, expansion, conquest, 
capture, offshoots." Structures and identities attempt to fix the truth in a knowable form. Yet nothing is ever in a state of permanent immovability. Everything is always crossing over into something else, decomposing and recomposing itself beneath the identities truth would like to erect.

In die lig van die bespreking van die tussenruimte waarin Krog haar as vertaler bevind, verkry die gedigsiklus "Country of grief and grace" (DLS 95) / "land van genade en verdriet (K 37) 'n bykomende betekenis, afgesien van die uitsluitlik politieke:

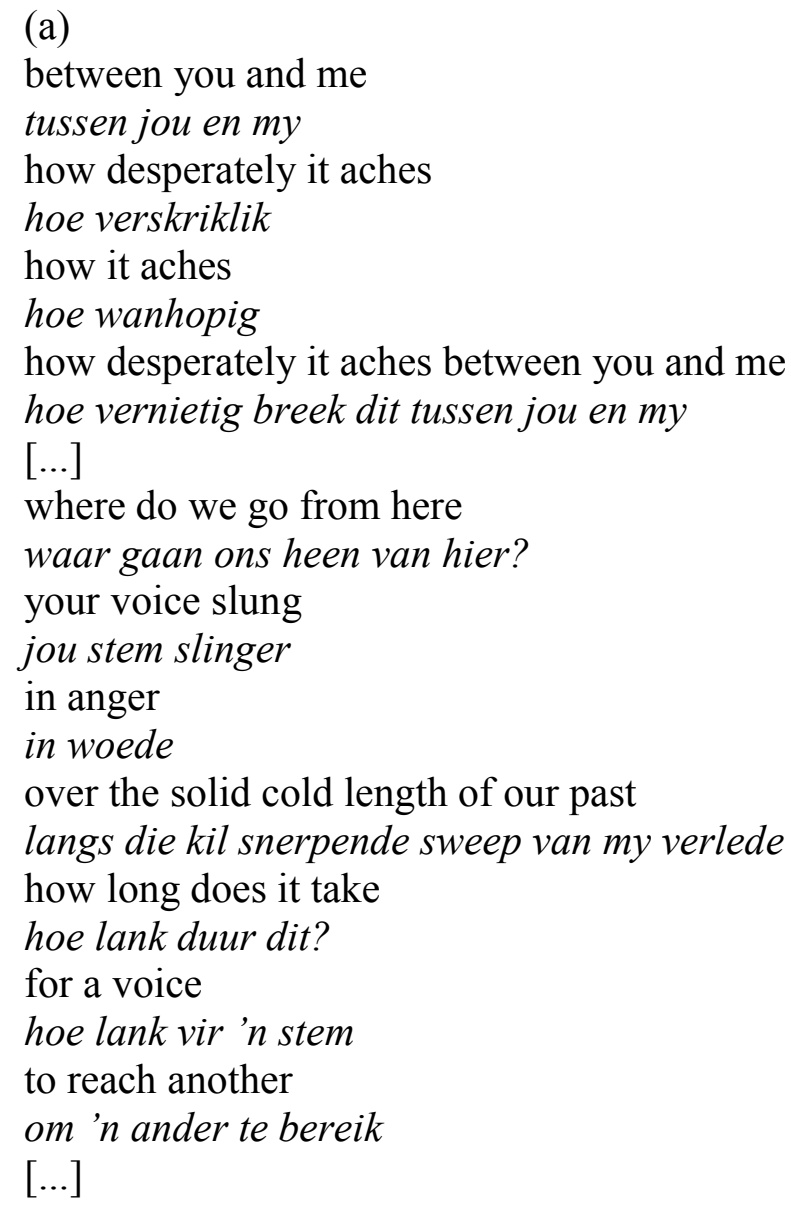

Gedig (a) se eerste strofe sou gelees kon word as 'n verwysing na Engels ${ }^{30}$ en Afrikaans, waar die stem van die ander in woede geslinger word oor die skrywer wat haar stem laat uitreik na die ander, verby die grense van waarheid en vernietiging, ter wille van oorlewing, groter erkenning, 'n groter teenwoordigheid in die land wat behoort aan "the voices of those who live in it."

(b)

in the beginning is seeing

in die begin is sien

seeing for ages

\footnotetext{
${ }^{30}$ Die ander stem sou ook 'n swart stem kon wees na aanleiding van die titel van die gedig "land van genade en verdriet" en die konteks van landskap, taal en identiteit (vergelyk Van Coller \& Odendaal 2003; Viljoen 2002).
} 
sien vir eeue

filling the head with ash

die kop vul met as

no air

geen suurstof

no tendril

geen spriet

now to seeing speaking is added

by sien word eindelik woord gevoeg

and the eye plunges into the wounds of anger

en die oog stort af in die woedende wond

seizing the surge of language by its soft bare skull

hoor! hoor die opwel van medemenslike taal

in haar sagte weerlose skedel

$[\ldots]$

Die direkte verwysing in gedig (b) na die "soft bare skull" van taal, waarvan die titel van die boek Country of my skull waarskynlik afgelei is, dui op die broosheid, indien nie die leegheid nie, van taal, en dit is in gedig (f) waar die digter die beliggaamde ervaring wat taal is artikuleer:

it breathes becalmed ${ }^{31}$

sy haal asem

after being wounded

gekalmeer na die litteken

in its wondrous throat

aan haar wonderbaarlike keel

in the cradle of my skull

in die wieg van my skedel sing dit

it sings it ignites

ontbrand dit

my tongue my inner ear the cavity of heart

my tong my binneste oor die gaping van my hart

shudders towards the outline

sidder vorentoe na die buitelyn

new in soft intimate clicks and gutturals.

van 'n woordeskat nuut in sag, intieme keelklanke

In gedig (g) stel Krog die titel van haar volgende Engelse bundel, Body bereft, aan die leser bekend:

this body bereft

die liggaam beroof

this blind tortured throat

die blind gefolterde keel

[...]

${ }^{31}$ Die woord "it" is dubbelsinnig: in een opsig kan dit na die land verwys, in 'n ander opsig na taal (Afrikaans). Let ook op die verskil tussen die gebruik van die onpersoonlike voornaamwoord "it" in Engels en "sy" en "haar" in Afrikaans in die eerste strofe, en die oorgang na "my" in strofe 2 in Engels en Afrikaans. 
Die liggaam, die teks, die taal van die digter word op die voorgrond gedwing, en dit, volgens Nel (2008:52), "sinspeel op die liggaam wat beroof is - daar is gevolglik 'n element van verlies en rou ingebed in die titel." Die verlies en rou dui egter nie slegs op liggaamlike aftakeling nie; dit sou ook kon verwys na die verlies en rou inherent in die digter (Krog) se naderbeweeg aan die Engelse veld in Suid-Afrika deur middel van vertaling, en die vrees vir die aftakeling (as skrywer) en verlies wat onvermydelik daarmee gepaardgaan. Dit verwys na die taal en die poësie wat deur die skryf in Engels geroof kan word. Die spel tussen die Afrikaanse titel, wat doelbewus na die taal- of skryfhandeling verwys, en die Engelse titel is op sigself ' $n$ belangrike element in die verstaan van die stryd waarna hierbo verwys word - beide funksioneer as intertekste van mekaar.

Op metafiksionele vlak funksioneer Body bereft dus nie slegs as ' $n$ vertaling of herdigting van Krog se Afrikaanse gedigte in Verweerskrif nie; daar is veel meer fasette daaraan wat verband hou met die teenwoordigheid van die kontroversiële digter en skrywer in 'n literêre veld waar sy nie so welkom voel nie. ${ }^{32}$ Hoewel die twee digbundels op die oog af as spieëlbeelde van mekaar voorkom, bevat Body bereft drie gedigte wat nie in Verweerskrif opgeneem is nie: "writing ode" (BB 33) wat 'n herdigting is van "skryfode" (K 66), "letter-poem lullaby for Ntombizana Atoo" 33 (BB 57) wat 'n herdigting is van "slaapliedjies vir Ntombizana Atoo" (K 79), en "farewell" (BB 65) wat 'n herdigting is van die gedig "afskeid" uit die gedigsiklus "Van litteken tot rivier" (K 100). Dit is vertalings wat nie oorspronklik in Down to my last skin opgeneem is nie, maar wat na my mening essensieel is vir Krog se oeuvre in Engels. Dit is veral "writing ode" wat 'n sentrale posisie in die bundel beklee omdat dit aan die Engelse leser die wese van Krog se poëtika - haar geartikuleerde habitus - weerspieël.

\section{Slot}

'n Mens kan aanvoer dat Krog op ten minste twee maniere of vlakke die revolusionêre potensiaal wat volgens Deleuze en Guattari (1986) opgesluit lê in die mineuraanwending van taal, binne 'n majeurletterkunde aanwend. In die eerste plek, met die verskyning van haar eerste digbundel, skryf sy binne die Afrikaanse literêre veld wat op daardie stadium as 'n majeurletterkunde binne Suid-Afrika beskou is. Afrikaans as taal was 'n majeurtaal wat die institusionalisering daarvan betref. Binne hierdie opset was Krog se styl minder konvensioneel en haar onderwerpe selfs nog meer uitdagend. Dit is egter veral met die publikasie van Country of my skull en A change of tongue in Engels, waar Krog verder gaan en binne die majeurtaal wat Engels is (teenoor Afrikaans), 'n tipe (Suid-Afrikaanse) Engels (met 'n sterk Afrikaanse ondertoon) gebruik wat as't ware as 'n mineuraanwending van die majeurtaal funksioneer (vergelyk Pakendorf 1993).

Waar vernuwing of innovasie binne die polisisteemteorie gekoppel word aan dit (literêre werk of skrywer) wat vanaf die periferie na die sentrum van die literêre sisteem "beweeg", en sodoende 'n sentrale posisie inneem, sou die omgekeerde kon geld binne Deleuze en Guattari se raamwerk: 'n nuwe manier van gebruik wat die aantrekkingskrag van 'n hoër, dominante orde teenstaan en 'n nuwe literêre kontinent of ruimte (in Bhabha se raamwerk) daarstel wat

\footnotetext{
${ }^{32}$ Die Unheimliche van Freud is hier van belang. Die abjekte - hier, Krog se skryf en teenwoordigheid in die Engelse literêre veld - verdwyn nooit nie. Dit bestaan op die periferie van bewussyn, soveel so dat daar altyd 'n vrees bestaan by die subjek van 'n verlies aan identiteit en 'n terugkeer na die moeder se buik (McAfee 2004:48). ${ }^{33}$ Die Engelse weergawe verskyn die eerste keer in Chapman se A new century of South African poetry (2002:264). Hier word die woorde "letter-poem" bygevoeg by die titel.
} 
nóg konformerend nóg idealisties is; wat Krog nóg aan die outonome pool van die literêre veld plaas nóg aan die heteronome pool van kulturele produksie. In Country of my skull en A change of tongue skep Krog in 'n mate so 'n ruimte, en weer in Verweerskrif en Body bereft, vernaam op abjekte vlak. Op dié manier baan sy die weg vir die konseptualisering van 'n internasionale en kosmopolitiese kultuur wat die inskripsie en artikulasie van die hibriditeit van kultuur as grondslag het. Krog beskou vertaling as "die transformasie van 'n teks vanuit 'n magtelose tot 'n magtiger taal; die transformasie van 'n magtige teks wat magteloos gemaak word deur 'n magtelose taal, word bemagtig, kom tot sy reg in en deur die magtige taal" (Krog 2002b:2).

Krog se vertaling en vertalings in Engels belig wat Deleuze en Guattari (1987:106) beskryf as 'n majeurtaal wat 'n mineurgedaante aanneem - daar is nie twee tale nie,

rather two usages or functions of languages [...] Minor languages are characterized not by overload and poverty in relation to a standard or major language, but [...] like a minor treatment of the standard language, a becoming of the major language (ibid:105),

aangesien taal altyd 'n mengsel is,

a schizophrenic mélange, a Harlequin costume in which very different functions of language and distinct centers of power are played out, blurring what can be said and what can't be said.

\section{Bronnelys}

Bakhtin, M.M. 1984. Rabelais and his world. Vert. Hélène Iswolsky. Bloomington: Indiana University Press.

Beukes, M. 1999. Antjie Krog se "man ek lus 'n twakkie": eksemplaarteks van ginogenese as diskoers van mag. Tydskrif vir Geesteswetenskappe 39(2):193-203.

Bhabha, H. 1994. The location of culture. New York: Routledge.

Bourdieu, P. 1977. Outline of a theory of practice. Vert. Richard Nice. Cambridge: Cambridge University Press.

Bourdieu, P. 1993. The field of cultural production. Cambridge: Polity Press.

Breckenridge, C.A., Chakrabarty, D., Bhabha, H.K. \& Pollock, S. 2000. Cosmopolitanisms. Public Culture 12(3):577-589.

Breytenbach, B. 2008. Veil of footsteps: (Memoir of a nomadic fictional character). Kaapstad: Human \& Rousseau.

Breytenbach, K. 2009. Onderhoud met navorser, 22 Januarie 2009.

Brümmer, W. 2006. Krog: "Met hierdie liggaam is ek”. Die Burger, 2 Junie:15-17. 
Butler, J. 2001. Giving an account of oneself. Diacritics 31(19):22-40.

Chapman, M. 1996. Southern African literatures. Londen: Longman.

Chapman, M. (red.). 2002. The new century of South African poetry. Johannesburg: Ad Donker.

Cloete, M. 2001. Antjie Krog breaks fresh earth. Independent on Sunday, 2 Junie:12.

Coetzee, J.M. 2007. Diary of a bad year. Londen: Harvill Secker.

Conradie, P. 1996. Geslagtelikheid in die Antjie Krog-teks. Universiteit Wes-Kaapland.

Crous, M. 2002. Die diskoers van Antjie Krog se Lady Anne. Ongepubliseerde D.Littproefskrif. Universiteit van Stellenbosch.

De Kock, L. 2000. Voices of the earth. Mail \& Guardian, 17-23 November:9-10.

De Kock, L. 2001. South Africa in the global imaginary: an introduction. Poetics Today 22(2):263-298.

De Lange, J. 2006. Krog se nuutste verweer van bloed en ink. Rapport, 16 April:4-5.

Deleuze, G. \& Guattari, F. 1986. (1975 Fr.) Kafka. Toward a minor literature. Vert. Dana Polan. Minneapolis: University of Minnesota Press.

Deleuze, G. \& Guattari, F. 1987. (1980 Fr.) A thousand plateaus. Capitalism and schizophrenia. Vert. B. Massumi. Minneapolis: University of Minnesota Press.

Douglas, M. 1966. Purity and danger. Londen: Routledge.

Dumas, A., Laberge, S. \& Straka, S.M. 2005. Older women's relations to bodily appearance: the embodiment of social and biological conditions of existence. Ageing and Society 25:883902.

Garman, A. 2007. Antjie Krog and the accumulation of "media meta-capital". Current Writing 19(2):1-23.

Gray, S. 1997. Southern African literature: an introduction. Kaapstad: David Philip.

Gray, S. 2006. Letting it (all) hang out. Mail \& Guardian, 17 Maart. Beskikbaar by: www.chico.mweb.co.za/art/2006/2006mar/060317-body.html (Besoek 10 November 2009)

Grosz, E. 1990. The body of signification. In Fletcher, J. \& Benjamin, A. (reds.). 1990. Abjection, melancholia, and love. The work of Julia Kristeva. Londen: Routledge. 80-103.

Grosz, E. 1994. Volatile bodies: toward a corporeal feminism. Bloomington: Indiana University Press. 
Hambidge, J. 1996. Poësiekroniek: nommer 4: book reviews. Tydskrif vir Letterkunde 34(3):113-125.

Hambidge, J. 2009. Onderhoud met Louise Viljoen tydens die bekendstelling van Ons ongehoorde soort, 30 Mei 2009, Stellenbosch.

Heilbron, J. \& Sapiro, G. 2007. Outline for a sociology of translation. Current issues and future prospects. In Wolf, M. \& Fukari, A. (reds.). 2007. Constructing a sociology of translation. Amsterdam: John Benjamins. 93-107.

Heywood, C. 2004. A history of South African literature. Cambridge: Cambridge University Press.

Holtzhausen, E.J. 2001. Krog peels the everyday skin away to bare her poetic soul. Cape Times, 6 April:6.

Jones, A.R. 1997 (1981). Writing the body: toward an understanding of l'écriture féminine. In Warhol, R.R. \& D.P. Herndl. (reds.). 1997. Feminisms: an anthology of literary theory and criticism. Houndmills: Macmillan. 370-383.

Jonker, I. 2007. Black butterflies: selected poems. Vert. André Brink \& Antjie Krog. Kaapstad: Human \& Rousseau.

Kahn, J. G.d. About Sharon Olds. Beskikbaar by: www.english.illinois.edu/maps/poets/m r r olds/about.htm (Besoek 1 Februarie 2013)

Kannemeyer, J. 1988. Die Afrikaanse literatuur 1652-1987. Kaapstad: Human \& Rousseau.

Kennedy, D. 2006. Krog's hot pen flushes out myths about ageing. Cape Times, 20 Junie:7-9.

Kristeva, J. 1982. Powers of horror. An essay on abjection. New York: Columbia University Press.

Kristeva, J. 1986. Revolution in poetic language. In Moi, R. (red.). 1986. The Kristeva reader. New York: Columbia University Press. 89-136.

Kristeva, J. 2004. French theory. Irish Pages 2(2):201-214.

Krog, A. 1970. Dogter van Jefta. Kaapstad: Human \& Rousseau.

Krog, A. 1981. Otters in bronslaai. Kaapstad: Human \& Rousseau.

Krog, A. 1989. Lady Anne. Emmarentia: Taurus.

Krog, A. 1995. Relaas van 'n moord. Kaapstad: Human \& Rousseau.

Krog, A. 1997. Account of a murder. Vert. Karen Press. Johannesburg: Heinemann. 
Krog, A. 1998. Country of my skull. Johannesburg: Random House.

Krog, A. 1999-2000. Excerpts from a diary to Timbuktu. Mail \& Guardian, 23 Desember 1999 - 6 Januarie 2000:44.

Krog, A. 2000a. Kleur kom nooit alleen nie. Kaapstad: Kwela.

Krog, A. 2000b. Down to my last skin. Johannesburg: Random House.

Krog, A. 2002a. Met woorde soos met kerse. Kaapstad: Kwela.

Krog, A. 2002b. moet hierie woorde soes moet kerse - 'n oorsig oor verskeie vertalingsprojekte. Ongepubliseerde Langenhoven-gedenklesing. Universiteit van Port Elizabeth.

Krog, A. 2003. A change of tongue. Johannesburg: Random House.

Krog, A. 2004a. die sterre sê 'tsau'. /Xam-gedigte van Diäkwain, Kweiten-ta-//ken, /A!kúnta, /Han $\neq$ kass'o en //Kabbo. Gekies en versorg deur Antjie Krog. Kaapstad: Kwela.

Krog, A. 2004b. the stars say 'tsau'. /Xam poetry of Diäkwain, Kweiten-ta-//ken, /A!kúnta, /Han $\neq k a s s ' o$ and //Kabbo. Selected and adapted by Antjie Krog. Kaapstad: Kwela.

Krog, A. 2005a. 'n Ander tongval. Kaapstad: Tafelberg.

Krog, A. 2005b. "I, me, me, mine!": Autobiographical fiction and the "I". English Academy Review 22:100-107.

Krog, A. 2005c. Persoonlike e-pos-korrespondensie met die navorser, 22 Augustus 2005.

Krog, A. 2006a. Verweerskrif. Roggebaai: Umuzi.

Krog, A. 2006b. Body bereft. Roggebaai: Umuzi.

Krog, A. 2007. Persoonlike e-pos-korrespondensie met navorser, 7 Mei 2007.

Krog, A. 2009. Begging to be black. Kaapstad: Random House.

Krog, A. 2013. Skinned. Kaapstad: Umuzi.

Lanoye, T. 2002. Mamma Medea: na Apollonios van Rhodos en Euripides. Vert. Antjie Krog. Kaapstad: Queillerie.

Lefevere, A. 1981. Translated literature: towards an integrated theory. Bulletin of the Midwest Modern Language Association 14(1):68-78.

Lemaire, A. 1977. Jacques Lacan. Vert. David Macey. Londen: Routledge.

Mandela, N. 2001. Lang pad na vryheid. Vert. Antjie Krog. Florida Hills: Vivlia. 
Mansfield, N. 2000. Subjectivity. Theories of the selffrom Freud to Haraway. New York: New York University Press.

McAfee, N. 2004. Julia Kristeva. New York: Routledge.

Moi, T. 1999. What is a woman? Oxford: Oxford University Press.

My beautiful land. 1971. Sechaba 5(1):16.

Pope, D. Rich's life and career. G.d. Beskikbaar by: www.english.illinois.edu/maps/poets/ $\underline{\mathrm{m} \text { r } / \text { rich/bio.htm }}$ (Besoek 1 Februarie 2013)

Ndebele, N.S. 2006 (1991). Rediscovery of the ordinary: essays on South African literature and culture. Scottsville: University of KwaZulu-Natal Press.

Nel, A. 2008. Liggaam, teks en parateks in Antjie Krog se Verweerskrif. LitNet Akademies 5(3):1-24.

Nielsenbookdataonline. G.d. Beskikbaar by: www.Nielsenbookdataonline.com/bdol/auth/ searchresults.do (Besoek 1 Februarie 2013)

Pakendorf, G. 1993. Kafka, en die saak vir ’n "klein letterkunde”. Stilet 5(1):99-106.

Palmié, S. 2013. Mixed blessings and sorrowful mysteries. Second thoughts about "hybridity". Current Anthropology 54(4):463-482.

Richardson, G. 1998. Georges Bataille. Essential writings. Londen: Sage.

Roos, H. 1998. Perspektief op die Afrikaanse prosa van die twintigste eeu. In Van Coller, H.P. (red.). 1998. Perspektief en profiel. 'n Afrikaanse literatuurgeskiedenis. Deel 1. Pretoria: Van Schaik. 21-117.

Roos, H. 2006. Die Afrikaanse prosa 1997 tot 2002. In Van Coller, H.P. (red.). 2006. Perspektief en profiel: 'n Afrikaanse literatuurgeskiedenis. Deel 3. Pretoria: Van Schaik. 43104.

Rycroft, B. 2000. Krog sears away the layers of artifice. Cape Times, 19 Desember:11-12.

Sampson, L. 2008. Lifting the veil. Beskikbaar by: www.timeslive.co.za/sundaytimes/ article117974. ece?service (Besoek 1 Februarie 2013)

Sontag, S. 2003. Regarding the pain of others. Londen: Penguin.

Spies, L. 2006. Ongebluste kole van wellus en geluk. Die Burger, 15 Julie:9.

Van Coller, H.P. 2005. Revisiting the canon and the literary tradition: a South African case study. Tydskrif vir Literatuurwetenskap 21(1/2):29-47. 
Van Coller, H.P. \& Odendaal, B.J. 2003. Kleur kom nooit alleen nie (Antjie Krog) en Die burg van hertog Bloubaard (H.J. Pieterse): 'n poëtikale beskouing (Deel 1). Stilet 15(1):36-64.

Van Coller, H.P. \& Odendaal, B.J. 2005. Die verhouding tussen die Afrikaanse en Nederlandse literêre sisteme. Deel I: Oorwegings vir 'n beskrywende model. Stilet XVII(3):1-17.

Van Vuuren, H. 2006. 'Verweerskrif' tematies en tegnies vernuwend. Beeld, 17 April:9-10.

Van Woerden, H. 2000. Domein van glas. Vert. Antjie Krog. Kaapstad: Queillerie.

Van Wyk Smith, M. 1996. White writing/writing black: the anxiety of non-influence. In Smit, J.A., Van Wyk, J. \& Wade, J-P. (reds.). 1996. Rethinking South African literary history. Durban: Y Press. 71-84.

Venuti, L. 1998. Introduction. The Translator 4(2):135-144.

Verstraete, C. 2006. Plagiarism: the cultural outbreak. Ongepubliseerde MPhil-tesis. Universiteit van Kaapstad.

Vidal Claramonte, M.C. 2012. The map is not the territory: towards a minor translation. Perspectives: Studies in Translatology 20(3):269-284.

Viljoen, L. 2002. "Die kleur van mens": Antjie Krog se Kleur kom nooit alleen nie (2000) en die rekonstruksie van identiteit in post-apartheid Suid-Afrika. Stilet 14(1):20-49.

Viljoen, L. 2009. Ons ongehoorde soort. Beskouings oor die werk van Antjie Krog. Stellenbosch: SUN PReSS.

Visagie, A. 1999. Subjektiwiteit en vroulike liggaamlikheid in enkele tekste van Riana Scheepers en Antjie Krog. Literator 20(2):107-121.

Vita award for Krog's English work. 2001. Citizen, 22 Mei:21.

Von Flotow, L. 1997. Translation and gender: translating in the 'era offeminism'. Manchester: St. Jerome.

Vosloo, F.A. 2010. Om te skryf deur te vertaal en te vertaal deur te skryf: Antjie Krog as skrywer/vertaler. Ongepubliseerde D.Litt-proefskrif, Universiteit Stellenbosch.

Watson, S. 2005. Annals of plagiarism: Antjie Krog and the Bleek and Lloyd collection. New Contrast 33(2):48-61.

West, M.G. G.d. Celebrating the change. Beskikbaar by: www.melissagaylewest.com/ articles celebrating.htm (Besoek 1 Februarie 2013)

Young, I.M. 2005. On female body experience: "Throwing like a girl" and other essays. Oxford: Oxford University Press. 